\title{
Developing Low-Cost, High Performance, Robust and Sustainable Perovskite Electrocatalytic Materials in the Electrochemical Sensors and Energy Sectors: "An Overview"
}

\author{
Tse-Wei Chen ${ }^{1}$, Rasu Ramachandran ${ }^{2, *}$, Shen-Ming Chen ${ }^{3, *}$, Narayanasamy Kavitha ${ }^{4}$, \\ Kannaiyan Dinakaran ${ }^{4}$, Ramanjam Kannan ${ }^{5}$, Ganesan Anushya ${ }^{6}{ }^{\circledR}$, Nagulan Bhuvana ${ }^{7}$, \\ Tharini Jeyapragasam ${ }^{8}$, Vinitha Mariyappan ${ }^{3}{ }^{10}$, Selvarajan Divya Rani ${ }^{2}$ and Selvam Chitra ${ }^{9}$ \\ 1 Department of Materials, Imperial College London, London SW7 2AZ, UK; twchenchem@gmail.com \\ 2 Department of Chemistry, The Madura College, Vidya Nagar, Madurai 625 011, Tamil Nadu, India; \\ diviselvarajan30@gmail.com \\ 3 Electroanalysis and Bioelectrochemistry Lab, Department of Chemical Engineering and Biotechnology, \\ National Taipei University of Technology, No.1, Section 3, Chung-Hsiao East Road, Taipei 106, Taiwan; \\ vinithavicky80@gmail.com \\ 4 Department of Chemistry, Thiruvalluvar University, Vellore 632 115, Tamil Nadu, India; \\ nkavitharanjani@gmail.com (N.K.); kdinakaran@hotmail.com (K.D.) \\ 5 Department of Chemistry, Sri Kumaragurupara Swamigal Arts College, Srivaikuntam, \\ Thoothukudi 628 619, Tamil Nadu, India; tgrk2013@gmail.com \\ 6 Physics Research Centre, S.T. Hindu College, Nagercoil 629 002, Tamil Nadu, India; g.anushya7@gmail.com \\ 7 Department of Chemistry, Jeppiaar Institute of Technology, Sriperumbudur, Chennai 631 604, Tamil Nadu, \\ India; bhuvana_jerin@yahoo.com \\ 8 Rajarajan Institute of Science, Madurai 625 009, Tamil Nadu, India; tharinichem@gmail.com \\ 9 Department of Chemistry, Alagappa Govt Arts College, Karaikudi 630 003, Tamil Nadu, India; \\ schitrachem@gmail.com \\ * Correspondence: ultraramji@gmail.com (R.R.); smchen78@ms15.hinet.net (S.-M.C.)
}

Received: 1 July 2020; Accepted: 13 August 2020; Published: 16 August 2020

\begin{abstract}
Since its discovery in 1839, research on the synthesis and application of perovskite materials has multiplied largely due to their suitability to be used in the fields of nanotechnology, chemistry and material science. Appropriate changes in composition or addition of other elements or blending with polymers may result in new hybrid and/or composite perovskite materials that will be applied in advanced fields. In this review, we have recapitulated the recent progress on perovskite nanomaterial in solar cell, battery, fuel cell and supercapacitor applications, and the prominence properties of perovskite materials, such as excellent electronic, physical, chemical and optical properties. We discussed in detail the synthesis and results of various perovskite hybrid nanomaterials published elsewhere. We have also discussed the results of various studies on these low dimensional composite nanomaterials in broad sectors such as electronics/optoelectronics, batteries, supercapacitors, solar cells and electrochemical sensors.
\end{abstract}

Keywords: perovskite; nanomaterials; nanocomposite; electrochemical sensors; energy storage devices

\section{Introduction}

Perovskite-based materials have become a promising candidate, which can be applied in a modern scientific society, because of light-harvesting, basic structure, and unique properties for sustainable 
energy storage device [1-7]. The discovery of calcium titanate $\left(\mathrm{CaTiO}_{3}\right)$ in 1839 by the Russian mineralogist Perovski was regarded to be the origin of Perovskite, and materials with the same form of a crystal structure as $\mathrm{CaTiO}_{3}$ were known as Perovskite materials (structure) [8]. Generally, the chemical formula used to describe the perovskite materials is $\mathrm{ABX}_{3}$, where ' $\mathrm{A}$ ' and ' $\mathrm{B}$ ' are cations of different sizes and ' $X$ ' is an anion that binds to both, which are typically oxides or halogens. The ' $A$ ' atoms are bigger than the ' $\mathrm{B}$ ' atoms. The $\mathrm{A}$ and $\mathrm{B}$ locations can be replaced by either metal or semimetal from the periodic table [9]. The perovskite structure oxide has the general formula $\mathrm{ABO}_{3}$, as shown in Scheme 1 . The A cations such as calcium, lanthanum, lead and strontium are lower in valence and occupy 12-fold holes coordinated with oxygen. The B cations, such as cobalt, chromium, iron, nickel, titanium, and zirconium, reside in smaller six-fold (octahedral) coordination holes. Absolute or partial replacement of $A$ or $B$ cations with lower valence cations, such that the charge of $A$ and $B$ cations is less than +6 , causes vacancies in the oxygen lattice sites. This replacement allows the perovskite structure to achieve mixed ionic and electronic conductivity where electronic conductivity is provided by the transition metal cations [10]. Hybrid-based organic-inorganic halide-supported perovskite has lead to great potential and is very popular in renewable energy sources, unique electronic properties, and key materials for the development of perovskite solar cell (PSC)-based devices [11-13]. Wang et al. [14] used the first d-block metal-based perovskite oxides (FDMPOs), which received considerable attention for their promising electrocatalytic activity in the water oxidation reaction. The highly tunable process-based infiltration of cation layered perovskite (LPK) modified organic-inorganic hybrid methyl ammonium lead iodide (MAPS) film results in increased open-circuit voltage and conversion efficiency [15]. Chiang et al. [16] observed that highly efficient cost-affordable and sustainable planar organometallic perovskite/fullerene heterojunction solar cells were considered as potential candidates for high power conversion efficiency $(4.54 \%)$ with increased open circuit-voltage $(920 \mathrm{mV})$. Bromide-based $\left(\mathrm{CsPbBr}_{3} / \mathrm{CsPbBr}_{3}-\mathrm{CsPb}_{2} \mathrm{Br}_{5} / \mathrm{CsPbBr}_{3}-\mathrm{Cs}_{4} \mathrm{PbBr}_{6}\right)$ inorganic perovskite electrode materials have been used as the most promising candidate for solar cell applications. The heterojunction energy storage device showed reasonable power conversion efficiency $(10.17 \%)$ with excellent cyclic stability $(3000 \mathrm{~h})$ under thermal conditions (@ $100{ }^{\circ} \mathrm{C}$ ) [17]. Currently, batteries are considered as a primary prospective technology and have become key for applications in electric and hybrid vehicles [18]. Sun et al. [19] have synthesized Mn-doped $\mathrm{La}_{0.6} \mathrm{Sr}_{0.4} \mathrm{Co}_{1-\mathrm{x}} \mathrm{Mn}_{\mathrm{x}} \mathrm{O}_{3} /$ Super P electrode, which displayed their higher discharge capacity and long cyclic durability during the discharge-charge process. Different types of unconventional $\left(\mathrm{SmFeO}_{3}\right.$ and $\mathrm{Bi}$-doped $\left.\mathrm{SmFeO}_{3}\right)$ perovskite-based electrodes are being explored in lithium-ion batteries (LIBs). However, the developed perovskite catalysts $\left(\mathrm{SmFeO}_{3}\right.$ and $\mathrm{Sm}_{0.92(2)} \mathrm{Bi}_{0.08(2)} \mathrm{FeO}_{3}$ ) delivered discharged capacity values of 450 and $550 \mathrm{mAh} \mathrm{g}^{-1}$ at $5 \mathrm{~mA} \mathrm{~g}^{-1}$ [20]. A new approach to enhance the charge capacity of $\mathrm{Ba}_{0.5} \mathrm{Sr}_{0.5} \mathrm{Co}_{0.8} \mathrm{Fe}_{0.2} \mathrm{O}_{3-\delta}$ perovskite electrode catalyst, which can be immobilized with lithium sulphide $\left(\mathrm{Li}_{2} \mathrm{~S}\right)$, is also available. In this embedded lithium-sulfur (Li-S) batteries, the bifunctional LiPS promoter provides an ultralow capacity decay rate of $0.050 \%$ in 400 cycles, a substantially improved rate capability of $753 \mathrm{mAh} \mathrm{g}^{-1}$ at $2 \mathrm{C}$ (three fold larger than the pristine Li-S cell), and a stable areal capacity with high S loading $\left(2.5-5.2 \mathrm{mg} \mathrm{cm}^{-2}\right)$ for practical applications [21]. Cao et al. [22] have developed a cubic pre-expanding perovskite iron fluoride $\left(\mathrm{KFeF}_{3}\right)$-based open framework cathode for sodium-ion batteries (SIBs), the displayed Na-storage reversible capacity value of $110 \mathrm{mAh} \mathrm{g}^{-1} @ 1 \mathrm{C}$. The development of new sustainable-based green/clean fuel cell energy sources has attracted great attention for commercially available energy storage devices for minimal noise, and low emissions with high power conversion efficiency [23-25]. An interesting amorphous iron oxide-modified $3 \mathrm{D}$ heterostructured $\mathrm{SrSc}_{0.2} \mathrm{Co}_{0.8} \mathrm{O}_{3-\delta}$ (SSC) porous perovskite catalyst showed superior ORR with high power density [26]. $\mathrm{Ba}_{0.5} \mathrm{Sr}_{0.5} \mathrm{Co}_{0.2} \mathrm{Fe}_{0.2} \mathrm{O}_{3-\delta}$ perovskite oxide-modified acetylene black (BSCF/AB) composite materials should exhibit and significantly influence their catalytic activity (ORR) [27]. Zhou et al. [28] have used a prominent novel $\mathrm{SrSc}_{0.175} \mathrm{Nb}_{0.025} \mathrm{Co}_{0.8} \mathrm{O}_{3-\delta}$ (SSNC) cathode electrode material that demonstrated excellent ORR reactivity under low temperature $\left(\leq 600^{\circ} \mathrm{C}\right)$ conditions. Supercapacitors have attracted worldwide research, because of their versatile unique properties, high specific power and rapid charging-discharging process [29]. Sol-gel strategies have 
gained a significant interest in the synthesis of perovskite-type oxides due to their excellent chemical homogeneity and ability to control the size, morphology, chemical properties and texture of the particles. Shao et al. [29] have demonstrated a new approach to the manufacture of perovskite oxides, in which the mesoporous $\mathrm{LaFeO}_{3}$ is synthesized by calcinating the MIL-100-Fe gel prototype. The derived electrode material retained the benefits of gel and MOF, with a high area of $41 \mathrm{~m}^{2} \mathrm{~g}^{-1}$ and rich mesoporosity. This distinctive structure provides excellent electrode material charge transfer capability, resulting in a high specific capacity of $241.3 \mathrm{~F} \mathrm{~g}^{-1}\left(67.1 \mathrm{mAh} \mathrm{g}^{-1}\right)$ at $1 \mathrm{~A} \mathrm{~g}^{-1}$ [30]. Perovskite-based $\mathrm{La}_{\mathrm{x}} \mathrm{Sr}_{1-\mathrm{x}} \mathrm{CoO}_{3-\delta}$ (LNF- $x$ ) nanofiber materials are considered as potential electrode materials for symmetric and asymmetric supercapacitor devices. The nanofiber possessed a high surface to volume ratio and the estimated capacitance value of $747.75 \mathrm{~F} \mathrm{~g}^{-1} @ 2 \mathrm{~A} \mathrm{~g}^{-1}$ under aqueous $\left(1 \mathrm{M} \mathrm{Na}_{2} \mathrm{SO}_{4}\right)$ electrolytic conditions [31]. Recently, hierarchical mesoporous nanostructured lanthanum chromate $\left(\mathrm{LaCrO}_{3}\right)$ perovskite oxide has been given much consideration, because of its efficient electrochemical performance with extremely low charge transfer resistance [32]. There are increasing demands and considerable interest for electrochemical sensor techniques, which can be recommended owing to their simple handling, high sensitivity, and environmentally friendly nature [33]. $\mathrm{ZnSnO}_{3}$ perovskite nanomaterials have been greatly used in the electrochemical sensing of biomarker troponin $T$ [34]. The stabilized power conversion efficiency of $19.0 \% @ 0.1 \mathrm{~cm}^{2}$ is attained by using the lightweight and mechanical flexible robust-based conducting polymer network electrode in perovskite solar cells [35]. The ideal and unique properties of the crystal structure of metal halide-based perovskite $\left(\mathrm{ABX}_{3}\right)$ electrode materials are shown in Scheme 1.

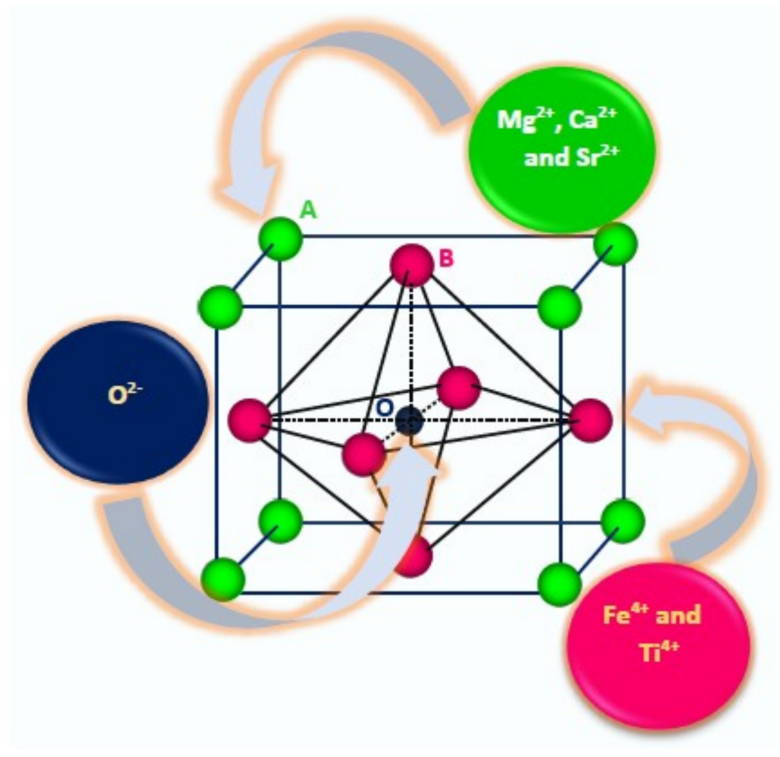

Scheme 1. Crystal structure of metal halide $\mathrm{ABX}_{3}\left(\mathrm{ABO}_{3}\right)$ type perovskite.

In this article, the principles of energy storage and the different characteristics of perovskite electrode materials for electrochemical energy storage (solar cells, batteries, fuel cells, sensors and supercapacitors) have been highlighted (Scheme 2). 


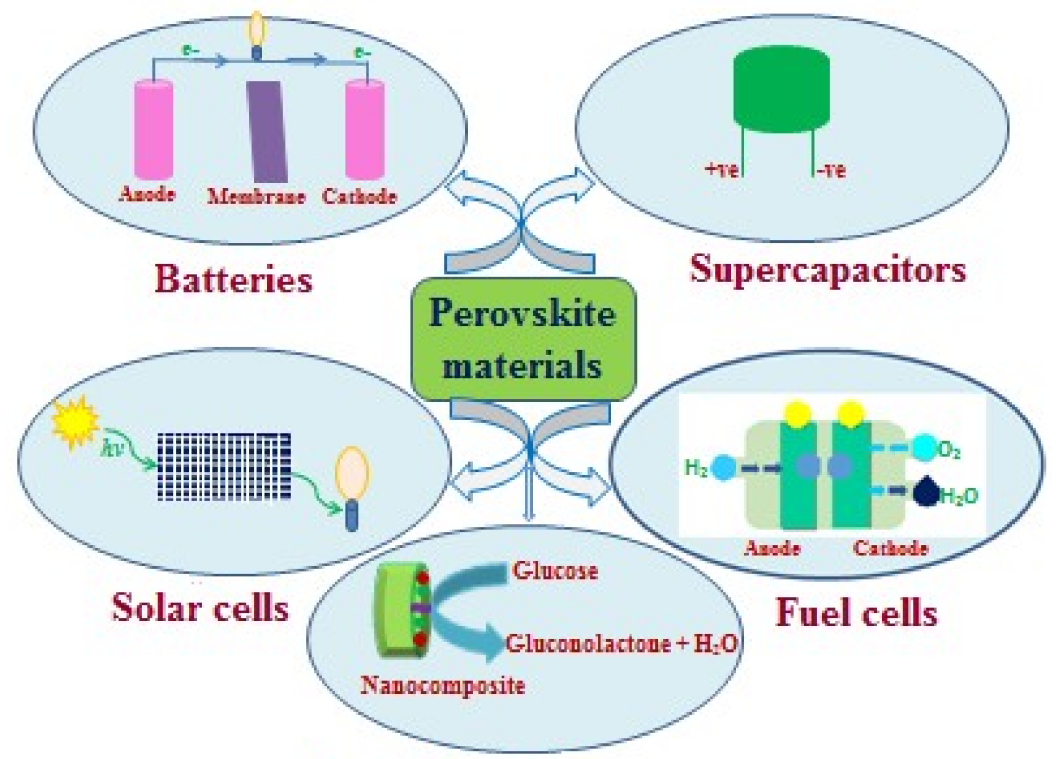

Electrochemical sensors

Scheme 2. Perovskite electrode materials for electrochemical (energy storage devices and electrochemical sensors) applications.

\section{Energy Storage Devices}

\subsection{Solar Cells}

Over the past decade, the increasing global energy demand and fascinating cyclic nature of green and clean energy sources have emerged as a great promise for high-efficiency solar cell device applications [36]. Recently, different kinds of nanomaterials MWCNTs [37], mesoporous carbon [38], mesoporous scaffold [39], carbon nanofiber [40], functionalized graphene [41] and graphene nanoplatelets [42] have received much attention for the study of high performance solar cell applications. The most commonly focused carbon supported electrode materials, like MWCNTs, fullerene and reduced graphene oxide, have emerged as a potential material for dye-sensitized solar energy storage devices [43-45].

The hole-conduct-free, compact layer-free and cost effective organic-inorganic-based PSCs are successfully employed for next generation high efficiency photovoltaic energy devices [46,47]. PSCs have excellent energy storage for the improvement of intrinsic stability of the absorbing layer with highly efficient promising future technology [48]. Interestingly, the Jiang group [49] has reported layer and hole-conductor-free mesoscopic $\mathrm{MPSC} / \mathrm{TiO}_{2}$ PSCs, which showed remarkable PCE of $13 \%$ and offer a simple, low cost and more effective photovoltaic energy device. The fabrication of transparent conducting polymer electrodes comprised of poly(3,4-ethylenedioxythiophene) and poly(styrene sulfonate) (PEDOT:PSS) can be accomplished by a spectrally-selective antireflection coating method. In these colorful PSCs (CPSCs), the PCE value ranges from 12.8 to $15.1 \%$ (red to blue colour), whereas the illuminated fluorinated indium tin oxide (FTO) electrode displayed from 11.6 to $13.8 \%$ (red to blue colour) [50]. The Wei group [36] developed inexpensive and high electrical conductive natured 3D potassium-ion supported graphene-based electrode (KIPIG) for sustainable PSC and DSSCs devices, which revealed its PCE of 7.81 and $9.12 \%$. Fabrication of PSCs (nanoparticulated bilayer, $\mathrm{SnO}_{2} / \mathrm{TiO}_{2}$ ) electrode has aroused one of the potential candidates for photovoltaic studies with impressive photovoltaic efficiency values of up to 15\% [51]. Chiang et al. [52] have developed a microwave-assisted PSC-based synthesis of indium-doped zinc oxide (IZO) for the study of solar cell applications. The authors have demonstrated a low fabrication cost, reasonable PCE ( $16 \%$ with a $V_{o c}$ value of $1.02 \mathrm{~V}, J_{o c}$ value of $22.86 \mathrm{~mA} \mathrm{~cm}^{-2}$ and the fill factor value of $69.43 \%$ ) and impression light-soaking stability. Recently, the novel, low-cost, facile processability and transparent 
hole-transporting materials (HTM) of CNTs-based semi-transparent methylammonium lead halide $\left(\mathrm{MAPbBr}_{3}\right)$ electrode materials were employed as PSC with the achieved efficiency value of up to $5.82 \%$. This $\mathrm{MAPbBr}_{3} / \mathrm{CNTs}$ electrode showed great potential applications in tandem solar cells, solar fuels, and solar-driven water splitting [53].

Dai et al. [54] have studied a novel silver nanowire (AgNWs)-based transparent electrode for PSCs. The AgNWs electrode showed a PCE of $11.0 \%$ with $V_{o c}$ of $0.96 \mathrm{~V}$ and $J_{s c}$ of $20.47 \mathrm{~mA} \mathrm{~cm}^{-2}$ (Figure 1). The new type of planar structured tin and germanium (Sn-Ge)-based PSCs was prepared by Ito et al. [55], which showed a noticeably improved efficiency value of $4.48 \%$. Very recently, a simple and cost-effective hollow structured two-dimensional titanium dioxide-based reduced-graphene scaffold ( $\mathrm{TiO}_{2} / 2 \mathrm{D}$ graphene) perovskite has been demonstrated as an outstanding electrode material for PSC applications. Figure 2a shows the top view porous structure and large surface area of rGS in AgNWs films. The results achieved reported a power conversion efficiency of $27 \%$ with good electrode stability (Figure 2b) [56].
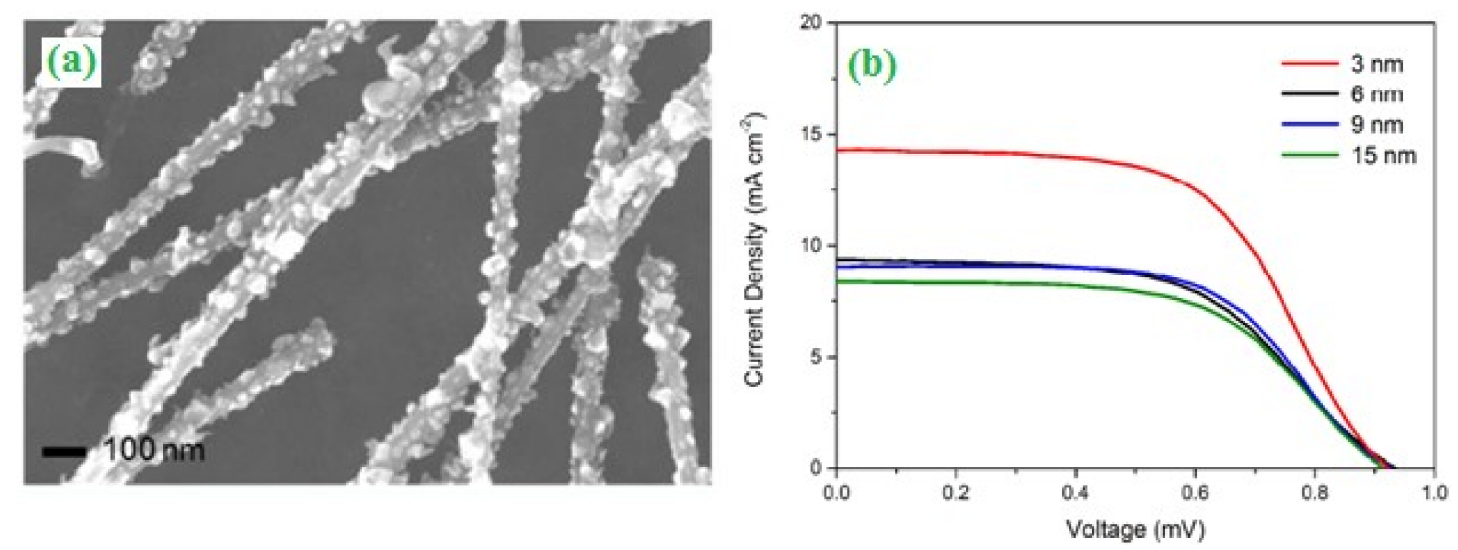

Figure 1. (a) SEM images of AgNWs films stored in ambient environment for one week directly on top of perovskite/hole transporting materials (HTM) active layer (b) $J-V$ curves of perovskite solar cells (PSCs) with different intermediate Au layer thickness illuminated from the AgNWs side. Reprinted with permission from [54]. Copyright (2016), American Chemical Society.
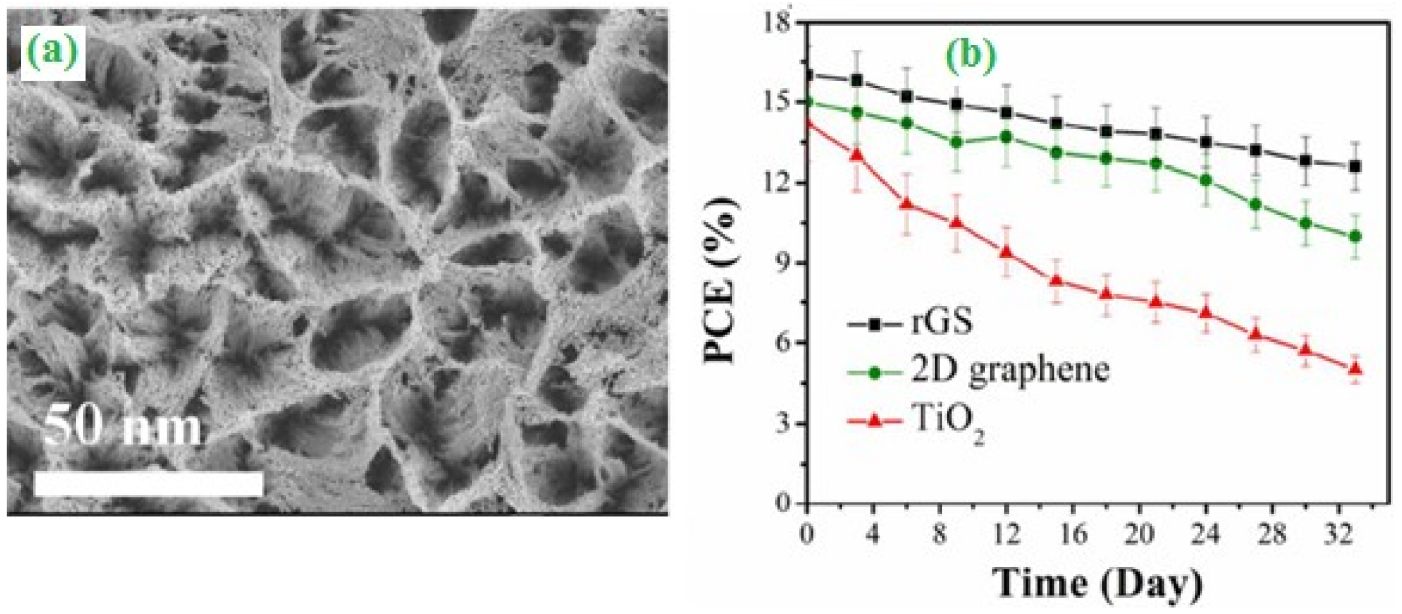

Figure 2. (a) SEM image of the reduced graphene scaffold (rGS) structure (Top view) (b) Stability of the devices in an ambient environment ( 65\% humidity) after encapsulation using UV-cured epoxy. Reprinted with permission from [56]. Copyright (2016), American Chemical Society.

\subsection{Batteries}

The successive developments of battery technology have attracted electric and hybrid vehicles, due to their excellent electrical conductivity, cost-effectiveness and potential applications in green 
energy devices $[18,57]$. Recent researchers have focused on surface-active morphological oriented nano structured electrode materials, which can be used for promising energy systems and the development of next generation commercialized LIBs [58,59]. The design and development of an efficient ultra-long porous perovskite-based $\mathrm{La}_{0.6} \mathrm{Sr}_{0.4} \mathrm{Co}_{0.8} \mathrm{Mn}_{0.2} \mathrm{O}_{3}$ nanofiber-supported $\mathrm{RuO}_{2}$ nanosheet electrode catalyst has been synthesized by the electrospinning method. The fabricated electrode materials can be used as an excellent electrode catalyst for an efficient durable rechargeable $\mathrm{Li}_{-} \mathrm{O}_{2}$ battery [60]. Miao et al. [61] synthesized Mn-based perovskite $\left(\mathrm{La}_{1 x} \mathrm{Y}_{x} \mathrm{MnO}_{3}\right.$, LYM-10) composite catalyst for metal-air batteries and found the maximum power density of $167 \mathrm{~mW} / \mathrm{cm}^{2}$ with good cyclic stability. Wang et al. [62] prepared the bifunctional electrocatalytic natured perovskite $\mathrm{Sr}_{0.9} \mathrm{Y}_{0.1} \mathrm{CoO}_{3-\delta}$-supported $\mathrm{CoO}$ via the electrospinning method, which showed improved electrochemical performances towards oxygen reduction (ORR) and oxygen evolution reaction (OER). The $\mathrm{Sr}_{0.9} \mathrm{Y}_{0.1} \mathrm{CoO}_{3-\delta}$ nanorod can increase their electrochemical properties for $\mathrm{Li}^{-\mathrm{O}_{2}}$ batteries with reduced voltage $(\sim 80-140 \mathrm{mV})$ (Figure 3). The successful mechanochemical synthesis of a novel electroactive silver molybdenum oxyfluoride (SMOF) perovskite $\mathrm{Ag}^{+}{ }_{3} \mathrm{Mo}^{6+}\left(\mathrm{O}_{3} \mathrm{~F}_{3}\right)$ cathode electrode can improve the volumetric capacitance value of $954 \mathrm{~A} \mathrm{~h} / \mathrm{L}$ of the $\mathrm{Ag}^{+}{ }_{3} \mathrm{Mo}^{6+}\left(\mathrm{O}_{3} \mathrm{~F}_{3}\right)$ nanostructure [63]. The development and design of flexible composite solid electrolytes (CSEs)-based PEO perovskite nanofiber networks has relatively good contact electrodes to achieve good mechanical properties and high ionic conductivity. The LiPEO-LiTFSI-LLTO/Li symmetric cell electrochemical impedance spectrum (EIS) exhibited low internal battery resistance and high $\mathrm{Li}^{+}$ion conductivity, and a capacity value of $135.0 \mathrm{mAh} \mathrm{g}^{-1}$ with reasonable cyclic stability of 300 cycles (Figure 4) [64]. The fabrication of $2 \mathrm{D}$ hybrid halide-based perovskite (HHP) $\left(\mathrm{CH}_{3}\left(\mathrm{CH}_{2}\right)_{2} \mathrm{NH}_{3}\right)_{2}\left(\mathrm{CH}_{3} \mathrm{NH}_{3}\right)_{2} \mathrm{~Pb}_{3} \mathrm{Br}_{10}$ solid electrolyte has been explored in secondary lithium-ion battery. The as-fabricated potential electrode lithium secondary battery with high temperature operation showed better reversible capacity value (242 $\mathrm{mAh} \mathrm{g}^{-1} @ 0.13 \mathrm{~mA} \mathrm{~cm}^{-2}$ ) [65]. On the other hand, 3D-methylammonium lead mixed halide and 2D-propylammonium-methylammonium lead bromide-based organohalide perovskite thin film electrodes reported capacity values of 500 and $\sim 375 \mathrm{mAh} \mathrm{g}^{-1}$ coupling with $\mathrm{Li}^{+}$intercalation and good cycling stability [66]. Ogunniran et al. [67] reported that the Mn-doped perovskite orthorhombic structured $\mathrm{Nd}_{0.9} \mathrm{Mn}_{0.1} \mathrm{FeO}_{3}$ nanoparticle could significantly increase its specific capacity value of $763 \mathrm{mAh} \mathrm{g}^{-1} @ 0.5 \mathrm{~A} \mathrm{~g}^{-1}$. The successful synthesis of cubic perovskite $\mathrm{BaSnO}_{3}$ embedded reduced graphene oxide $\left(\mathrm{BaSnO}_{3} / \mathrm{rGO}\right)$ composite for LIBs exhibited an excellent reversible capacity (1200 mAhg $\left.{ }^{-1} @ 0.5 \mathrm{C}\right)$ and outstanding long-term (100 cycles) stability [68]. Liu et al. [69] developed a nanotubular structure of a hierarchical-based $\mathrm{La}_{0.5} \mathrm{Sr}_{0.5} \mathrm{CoO}_{3-\mathrm{x}}$ (HPN-LSC) bifunctional electrode catalyst, which shows the upper limit capacity value of $500 \mathrm{mAh} \mathrm{g}^{-1}$ and long cyclic durability (50 cycles) (Figure 5). The cathode perovskite $\mathrm{Sr}_{2} \mathrm{CrMoO}_{6-\delta}$ (SCM) electrode materials have been synthesized by the sol-gel route, which displayed a controlling discharge capacity value of $600 \mathrm{mAh} \mathrm{g}^{-1}$ and the applied current density value of $75 \mathrm{~mA} \mathrm{~g}^{-1}$ [70]. The $3 \mathrm{D}$-ordered mesoporous $\mathrm{La}_{0.6} \mathrm{Sr}_{0.4} \mathrm{CoO}_{3-\delta}$ (3DOM LSC) perovskite is used as cathode for the $\mathrm{Li}^{-} \mathrm{O}_{2}$ air battery. LSC perovskite oxide could reasonably be attributed to increased surface area that enhanced its catalytic performance [71]. The noble metal-based multi-functional CoP-PrBa ${ }_{0.5} \mathrm{Sr}_{0.5} \mathrm{Co}_{1.5} \mathrm{Fe}_{0.5} \mathrm{O}_{5+\delta}$ (CoP-PBSCF) and perovskite-based electrode catalyst has been widely used for renewable energy devices where the optimized trifunctional electrode catalyst proved high power density $\left(138 \mathrm{~mW} \mathrm{~cm}^{-2}\right)$, lower overpotential in water splitting and more stability during charge/discharge polarization [72]. 

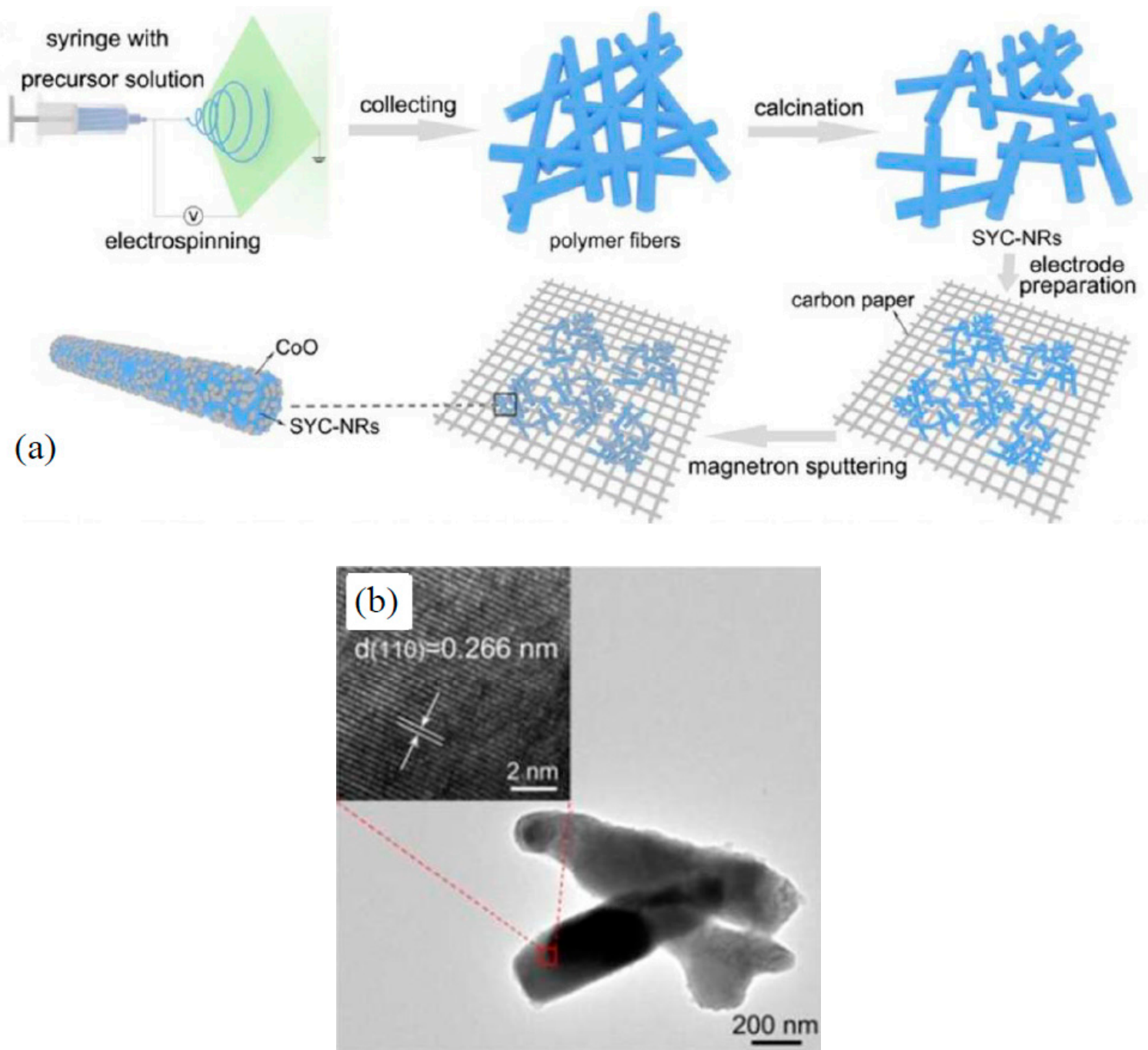

Figure 3. (a) Schematic illustration of strontium ytterbium cobalt-nanorods (SYC-NRs) synthesis through electrospinning and the CoO-coated electrode preparation process (b) TEM image of the synthesized SYC-NRs. Reprinted with permission from [62]. Copyright (2018), American Chemical Society.
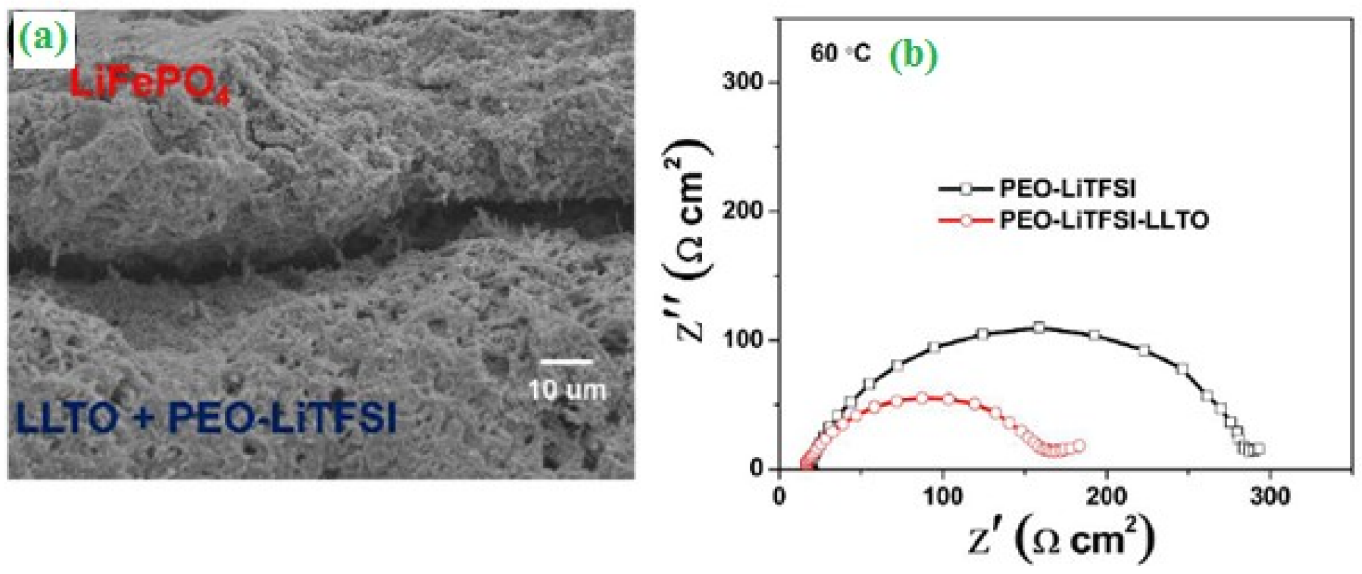

Figure 4. (a) The cross-sectional SEM image of the polyethyleneoxide- $\mathrm{LiC}_{2} \mathrm{~F}_{6} \mathrm{NO}_{4} \mathrm{~S}_{2}-\mathrm{Li}_{0.33} \mathrm{~L}_{0.557} \mathrm{TiO}_{3} /$ lithium ferrophosphate (PEO-LiTFSI-LLTO/LiFePO ${ }_{4}$ and PEO-LiTFSI-LLTO-O/LiFePO interface (b) The impedance spectra of the Li/PEO-LiTFSI/Li and Li/PEO-LiTFSI-LLTO/Li symmetric cells at $60^{\circ} \mathrm{C}$. Reprinted with permission from [64]. Copyright (2019), American Chemical Society. 

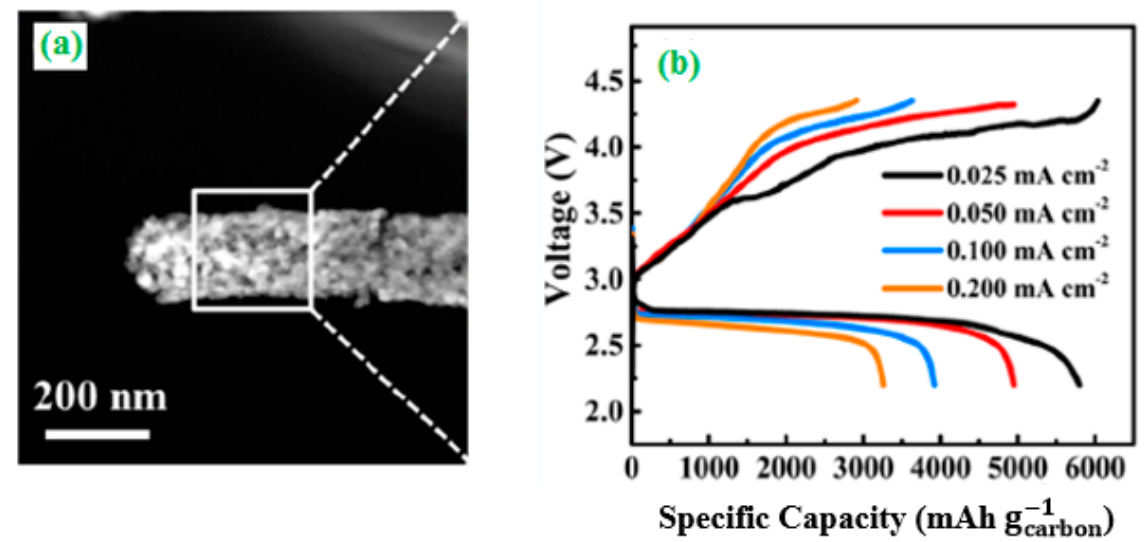

Figure 5. (a) Transmission electron microscopy and elemental distribution mapping (HAADFSTEM) image of hierarchical mesoporous-macroporous $\mathrm{La}_{0.5} \mathrm{Sr}_{0.5} \mathrm{CoO}_{3-\mathrm{x}}$ (HPN-LSC) (b) Galvanostatic discharge/charge curves of $\mathrm{Li}-\mathrm{O}_{2}$ batteries with the HPN-LSC/KB electrode at various current densities. Reprinted with permission from [69]. Copyright (2015), American Chemical Society.

\subsection{Fuel Cells (Oxygen Reduction)}

Solid oxide fuel cells (SOFC), can be used as an attractive new concept and promising cathode material for superior electrochemical performances of ORR. Recently, the development of active cathode materials has become a wider research area. In this review part, we have focused on the lanthanum-based cathode as the main material; the modifications made to be significantly improved in cathode activity and oxygen electrochemistry. Besides, there are numerous researchers who have contributed to the perovskite-based cathode materials. Here, some of the results and importance of their works are discussed in detail. Moreover SOFCs lead to friction and speed up the breakdown of cell components, respectively, owing to high temperature operation, which hampers the life span of SOFCs. Hence, in line with this, we have collectively presented some of the recent advancements in SOFC's cathode materials [73]. The ionic conductivity of SOFC's cathode materials was overcome by the functional electrolytes through-composed Perovskite $\mathrm{La}_{0.6} \mathrm{Sr}_{0.4} \mathrm{Co}_{0.2} \mathrm{Fe}_{0.8} \mathrm{O}_{3-\delta}$ as a cathode with sodium carbonate, which results in enhanced electronic and ionic conductivity, as reported by the Zhu group [74]. The resulting functional material shows good oxygen reduction characteristics at $550{ }^{\circ} \mathrm{C}$ and a maximum SOFC value of $700 \mathrm{~mW} / \mathrm{cm}^{2}$. A change in the composition of the metal oxide of cobalt $(0.8)$ and iron (0.2) resulted in a reduction in area-specific resistance $\left(\sim 0.14 \mathrm{mho} \mathrm{cm}^{2}\right)$. Additionally, the nickel and cobalt nitrate enhance the ORR kinetics and $\mathrm{Sr} / \mathrm{Ni} / \mathrm{Co}$ plays an important role in the reaction of electrode surface for further usage [75]. In line with the earlier study, the Hong group has developed a core-shell type LSCF113-214 to enhance the cathode performance and oxygen reaction for IT-SOFCs. Cubic phase LSCF 113 perovskite as the core was coated with Ruddlesden-Popper LSCF214 thin film to core-shell type by the solution coating method [76], resulting in lower polarization resistance of $0.17 \mathrm{mho} \mathrm{cm}^{2}$ compared to LSCF113 of $0.32 \mathrm{mho} \mathrm{cm}^{2}$ at $650{ }^{\circ} \mathrm{C}$. This enhancement was explained by the following: the lattice parameters of LSCF 113 mismatch with LSCF 214 in the core-shell material, therefore, the oxygen vacancy is greater, and this helps to absorb more oxygen molecules afterwards. Recently, a number of authors have studied the effects of various ions in LSCF materials and their influence has been reported.

Thus, the Budiman [77] group have studied in a detailed manner about the effect of Sr and Co composition in LSCF, which results in the surface oxygen exchange coefficient and oxide ion diffusivity concerning compositions of $\mathrm{Sr}$ and $\mathrm{Co}$; if the concentration of the $\mathrm{Sr} / \mathrm{Co}$ decreases the oxygen vacancy also decreases. Low dimensional materials such as nanometric level materials exhibit higher structural disorder, which depends on the method of preparation of material. Lamas group has tested the crystal structure of Co and Fe non-stoichiometric LSCF nanorods and found that the nanorods exhibit better electrochemical properties compared to the conventional micro-architecture cathode. Co-rich samples 
have more oxygen-defective sites and exhibit better ORR kinetics [78]. The Li [79] group has made detailed studies on the effect of doping the $\mathrm{Fe}, \mathrm{Ni}, \mathrm{Zn}$ in LSC on their electrochemical performance such as ORR; furthermore, their reduced oxides were tested for hydrogen oxidation reaction (HOR). They utilized $30 \mathrm{wt} \%$ of perovskite oxide prepared and $70 \mathrm{wt} \%$ samarium doped ceria- $\left(\mathrm{Li}_{0.67} \mathrm{Na}_{0.33}\right) \mathrm{CO}_{3} . \mathrm{Fe}$, $\mathrm{Ni}$, and $\mathrm{Zn}$ occupy the $\mathrm{Co}^{3+}$ sites, and Zn-LSC exhibits higher ORR compared to LSC, whereas Fe and $\mathrm{Ni}$-doped LSC decreases surface oxygen and, subsequently, ORR kinetics were also reduced. On the other hand, the reduction of these doped materials results in $\mathrm{Co}_{0.72} \mathrm{Fe}_{0.28}$, a core-shell type alloy-oxide nanoparticle (size: $\sim 20 \mathrm{~nm}$ ), which shows excellent $\mathrm{HOR}$; other oxides i.e., $\mathrm{ZnCo}_{2} \mathrm{O}_{4}, \mathrm{NiCo}_{2} \mathrm{O}_{4}$ show lower HOR. Here, HOR is the rate-determining step for the fuel activity and the single component $\mathrm{H}_{2}$ fuel cell exhibits a $P_{\max }$ of $239.1 \mathrm{~mW} \mathrm{~cm}^{-1}$ at $700{ }^{\circ} \mathrm{C}$. Similarly, Xie et al. [80] have studied $\mathrm{Sr}$ replaced with the effect of Barium (0.75) and calcium (0.25) with LSCF by the citric acid-EDTA sol-gel method. Here, Ca doping increases the electrical behavior of perovskite as it increases the whole concentration, additionally this shows more oxygen vaccines. Results enhanced the ORR process and the single-cell peak power density of $1102 \mathrm{~mW} \mathrm{~cm}^{-2}$ at $750{ }^{\circ} \mathrm{C}$. Zhang et al. [81] have reported the $\mathrm{LSCF} / \mathrm{CeO}_{2}$ nanofibers catalyst as a highly electroactive and robust material for the IT-SOFC cathode. The $\mathrm{LSCF} / \mathrm{CeO}_{2}$ nanofibers were developed by the co-axial electrospinning process. The precursors were separately mixed with PVP and subject to electrospinning and after the calcinations, the particles' size reduced to 30-50 nm. These porous nanofibers can help to attain higher ORR activity due to high specific surface area and area-specific resistance also reduced significantly for $\mathrm{LSCF} / \mathrm{CeO}_{2}$ nanofiber $\left(0.12 \mathrm{mho} \mathrm{cm}^{2}\right)$, compared to the LCSF nanofiber $\left(0.53 \mathrm{mho} \mathrm{cm}^{2}\right)$ and LSCF powder $\left(0.98 \mathrm{mho} \mathrm{cm}^{2}\right)$. The introduction of this $\mathrm{CeO}_{2}$ suppresses the segregation of the LSCF and its heterostructures that act as excellent ORR activity.

Enhanced electrochemical activity and catalytic durability of LSCF was achieved by a simple sol-gel method reported by the Liu group to modify the surface of $\operatorname{PrO}_{2-\delta}$ and $\operatorname{Pr}_{0.8} \mathrm{Ce}_{0.2} \mathrm{O}_{2-\delta}$ nanoparticles [82]. The $\mathrm{PrO}_{2-\delta}$-LSCF shows a $67 \%$ lowered specific resistance value of $\sim 0.241 \mathrm{mho} \mathrm{\textrm {cm } ^ { 2 }}$ at $600{ }^{\circ} \mathrm{C}$ compared to LSCF. Additionally, these $\mathrm{PrO}_{2-\delta} / \mathrm{LSCF}$ generate the active surface in LSCF and accelerate the oxygen vacancies and improved ionic conductivity leading to higher ORR. The durability of these catalysts was further improved by Ce ion, by adjusting the intrinsic activity of LSCF. Nadeem et al. [83] have investigated the effect of group III-A oxides such as $\mathrm{B}_{2} \mathrm{O}_{3}, \mathrm{Al}_{2} \mathrm{O}_{3}, \mathrm{Ga}_{2} \mathrm{O}_{3}$, and $\mathrm{In}_{2} \mathrm{O}_{3}$-doped LSCF and LSF perovskites by multiple steps. Among them, $\operatorname{In}_{2} \mathrm{O}_{3}$ shows significant improvements of about $13.73 \mathrm{wt} \%$ in LSCF and $7.88 \mathrm{wt} \%$ in LSF. In addition, the impregnation reduces the area-specific resistance of $0.41 \mathrm{mho} \mathrm{cm}^{2}$ to 0.27 (LSCF) and 0.99 to $0.39 \mathrm{mho} \mathrm{cm}^{2}$ (LSF), respectively. The electrochemical properties, i.e., oxygen electrocatalysis, are greatly enhanced by the chemical oxygen surface exchange coefficient of $4.53 \times 10^{-5} \mathrm{~cm} / \mathrm{s}$ (LSCF) and $2.39 \times 10^{-5} \mathrm{~cm} / \mathrm{s}$ (LSF) impregnation of $\mathrm{In}_{2} \mathrm{O}_{3}$. The proton migration and vapor formation are one of the major processes in the SOFC; the cathode microstructure is governed by these processes. In line with this, Lai et al. [84] have utilized $500 \mathrm{~nm}$ polystyrene nanospheres to make LSCF perovskite cathode. The results showed that $15 \mathrm{wt} \%$ of polystyrene polymer tailored cathode exhibits a much higher power density of about $620 \mathrm{~mA} / \mathrm{cm}^{2}$, which was due to the self-organized distribution by the polymer. Apart from the LSCF, a number of authors try to replace lanthanum, strontium, cobalt and iron with suitable ions to get better oxygen electrochemistry, but few of them are discussed further. The Ryu et al. [85] group developed $\mathrm{BaCo}_{0.4} \mathrm{Fe}_{0.4} \mathrm{Zr}_{0.1} \mathrm{Y}_{0.1} \mathrm{O}_{3-\delta}$ initially by the sol-gel, then by the pulse laser deposition method. The resulting material exhibits a highly nano sized porous morphology with an open-circuit voltage of $1.13 \mathrm{~V}$ at an operating temperature of $500{ }^{\circ} \mathrm{C}$. They reported that cathode material is cost effective, durable, and has high thermal stability for the long run. Additionally, the pulse laser deposition process results in a thin-film cathode without any morphological defect, i.e., materials that are not agglomerated in the nano dimension.

Zhang et al. [86] reported carbon dioxide tolerance cathode for oxygen electrochemistry compressed of $\mathrm{Nd}_{0.2} \mathrm{Sr}_{0.8} \mathrm{Nb}_{0.1} \mathrm{Co}_{0.9} \mathrm{O}_{3-\delta}$ perovskite. By altering the $\mathrm{Sr}, \mathrm{Co}, \mathrm{Nb}$ in the A-site, B-site synergy enhances the oxygen electro kinetic significantly, by low specific resistance of $0.037 \mathrm{mho}^{2} \mathrm{~cm}^{2}$ at $650{ }^{\circ} \mathrm{C}$. 
Additionally, the cathode shows high durability and $\mathrm{CO}_{2}$ tolerance i.e., 0.08 to $0.2 \mathrm{mho} \mathrm{cm}^{2}$ after 300 min under air atmosphere $\left(5 \% \mathrm{CO}_{2}\right)$. Namgung et al. [87] have developed $\mathrm{Sm}_{0.5} \mathrm{Sr}_{0.5} \mathrm{CoO}_{3-\delta}$ as catalyst-cathode backbone to enhance the durability of the catalyst performance. The prepared material exhibits high porosity in nature and a single phase, which directly reduces the cathode polarization significantly and exhibits the enhanced powder density of $1.57 \mathrm{~W} \mathrm{~cm}^{-2}$ at $700{ }^{\circ} \mathrm{C}$. A diagonal/rhombohedral structure of $\mathrm{La}_{0.5} \mathrm{Sr}_{0.5} \mathrm{Mn}_{1-x} \mathrm{Ni}_{x} \mathrm{O}_{3-\delta}$ (LSMN) transition metal-carbon hybrid nano crystal-based perovskite electrode can act as a well-known metal oxide redox couple and play the key role of boosting the intrinsic conduction with excellent electrocatalytic activity towards ORR (Figure 6) [88]. Development of a novel iron-based $\mathrm{Bi}_{0.5} \mathrm{Fe}_{1-x} \mathrm{Ti}_{x} \mathrm{O}_{3-\delta}$ (BSFT0.15) perovskite cathode is considered as an ideal electrode material for high performance of electrochemical properties (ORR) with outstanding $\mathrm{CO}_{2}$ tolerance ability (Figure 7) [89]. A systematic analysis of A-site (5 $\mathrm{mol} \% \mathrm{La}^{3+}$, $\mathrm{Sm}^{3+}$ and $\mathrm{Gd}^{3+}$ ) dopant and B-site $\left(5 \mathrm{~mol} \% \mathrm{Zr}^{4+}\right.$ and $\mathrm{Ce}^{4+}$ ) dopant substituting for $\mathrm{BaFeO}_{3-\delta}$ materials has been widely used as a cathode for SOFCs applications [90].

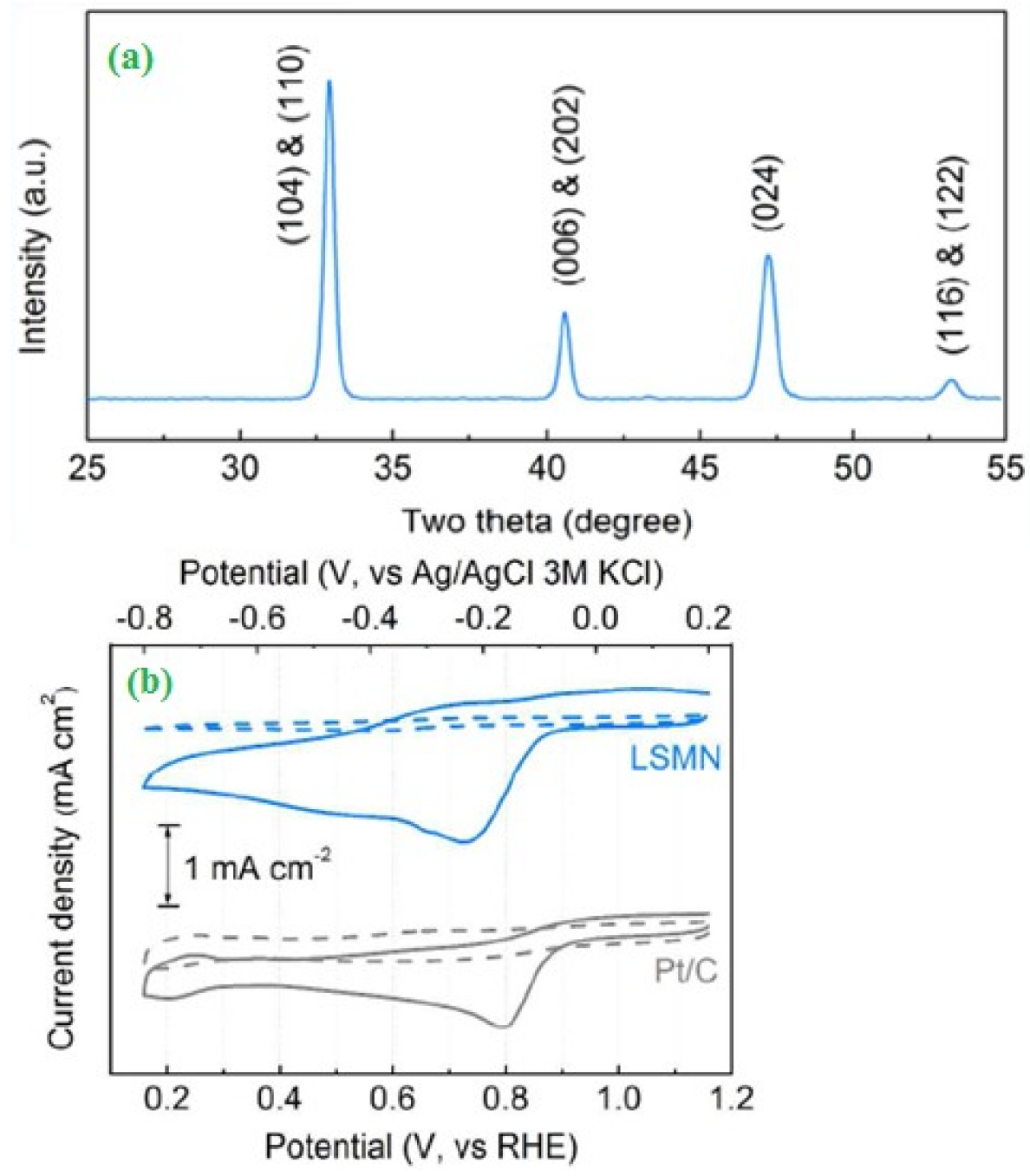

Figure 6. (a) $\mathrm{XRD}$ of $\mathrm{La}_{0.5} \mathrm{Sr}_{0.5} \mathrm{Mn}_{0.9} \mathrm{Ni}_{0.1} \mathrm{O}_{3-\delta}$ (LSMN)nanocrystals (b) Cyclic voltammograms of LSMN and $\mathrm{Pt} / \mathrm{C}\left(\mathrm{O}_{2}\right.$-saturated, solid line; $\mathrm{N}_{2}$-saturated, dashed line). Reprinted with permission from [88]. Copyright (2016), American Chemical Society. 

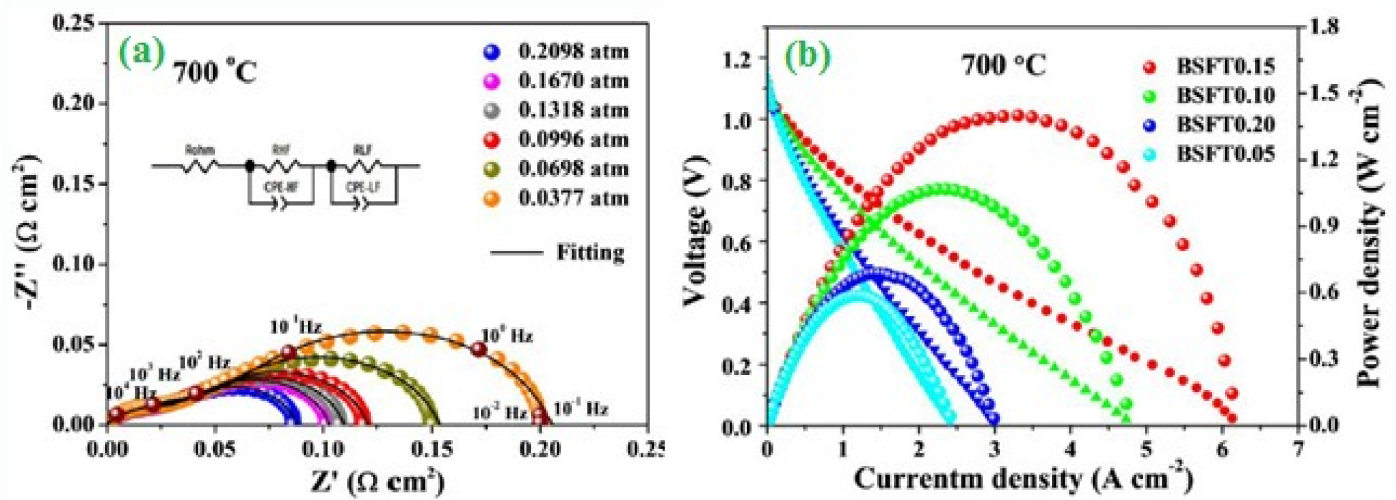

Figure 7. (a) The electrochemical impedance spectra of $\mathrm{Bi}_{0.5} \mathrm{Sr}_{0.5} \mathrm{Fe}_{1-\mathrm{x}} \mathrm{Ti}_{\mathrm{x}} \mathrm{O}_{3-\delta}$ (BSFT0.15) cathode (b) $I-V$ and $I-P$ curves of the cells with BSFT $x$ cathodes at $700{ }^{\circ} \mathrm{C}$. Reprinted with permission from [89]. Copyright (2019), American Chemical Society.

\subsection{Supercapacitors}

Supercapacitors have become an essential component to achieve a clean and safe environment. The goal of the research on supercapacitors is to lower the emission of pollutant gases from electric vehicles. Among several nanomaterials-based supercapacitors, those with perovskite as an active component are gaining attention due to their high charging-discharging speed and the increased high power density [91]. Zhou et al. [92] developed vertically integrated solar cell systems based on perovskite $/ \mathrm{MoO}_{3} / \mathrm{Au} / \mathrm{MoO}_{3}$ composites and electrochromic supercapacitor through the organo lead halide perovskite-based semitransparent photovoltachromic supercapacitors. Seamless integration has been reported by the authors from the photovoltachromic supercapacitors that gave the energy harvesting/storage without any negative impact. The perovskites materials that have a high specific surface area may be useful in enhancing supercapacitor functions. Sr/SrO-based perovskite metal oxides have attracted great attention for the development of supercapacitors due to their high electrical conductivity from electronic devices [93,94], for instance; Lang et al. developed Sr incorporated lanthanum manganite perovskite $\left(\mathrm{La}_{1 \mathrm{x}} \mathrm{Sr}_{\mathrm{x}} \mathrm{MnO}_{3}\right)$ as modified electrodes for supercapacitors, through the sol-gel technique [95]. The specific capacitance value of perovskite with $\mathrm{Sr}_{0.15}$ was found to be $102 \mathrm{~F} \mathrm{~g}^{-1}$ and lower intrinsic resistance was observed at $1 \mathrm{M} \mathrm{KOH}$. Similarly, Sr-based supercapacitors exhibited superior specific capacitance having around 5000 times of charging and discharging cycles [96]. A Sr-doped supercapacitor applied to the use of oxygen ions as a charge carrier in a supercapacitor for anion-intercalation was studied using $\mathrm{Co}_{3} \mathrm{O}_{4}, \mathrm{SrCoO}_{3-\delta}$ and $\mathrm{Ba}_{0.5} \mathrm{Sr}_{0.5} \mathrm{Co}_{0.8} \mathrm{Fe}_{0.2} \mathrm{O}_{3-\delta}$ as electrodes in an alkaline aqueous electrolyte. $\mathrm{SrCoO}_{3-\delta}$ was found to be a favourable electrode for supercapacitors because of its cycling stability, high capacity and proper cation leaching capacity (Figure 8) [97]. For supercapacitors, the anion-intercalated perovskite structured $\mathrm{SrCo}_{0.9} \mathrm{Nb}_{0.1} \mathrm{O}_{3-\delta}$ was used as an electrode in an aqueous $\mathrm{KOH}$ electrolyte, giving this model outstanding cycling stability and capacity. These supercapacitors had a gravimetric capacitance value of approximately $773.6 \mathrm{~F} \mathrm{~g}^{-1}$, high volumetric capacitance of around $2034.6 \mathrm{~F} \mathrm{~cm}^{-3}$, good cycling stability and $95.7 \%$ capacity retention over 3000 cycles [98].

The composite nanosystem of $\mathrm{La}_{1-x} \mathrm{Sr}_{x} \mathrm{BO}_{3-\delta}(\mathrm{x}=0-1 ; \mathrm{B}=\mathrm{Fe}, \mathrm{Mn}, \mathrm{Co})$ has been studied for anion-based pseudo capacitance behavior. The $\mathrm{La}_{1-x} \mathrm{Sr}_{x} \mathrm{BO}_{3-\delta}$ composition of a library of perovskite oxides composed of $\mathrm{La}_{0.2} \mathrm{Sr}_{0.8} \mathrm{MnO}_{2.7}$ showed a specific capacitance of $492 \mathrm{~F} \mathrm{~g}^{-1}$ at $5 \mathrm{mV} \mathrm{s}^{-1}$. Among the three pairs of asymmetric pseudo capacitors designed from $\mathrm{SrCoO}_{2.7}, \mathrm{La}_{0.2} \mathrm{Sr}_{0.8}$ $\mathrm{MnO}_{2.7}$, and brown millerite $\mathrm{Sr}_{2} \mathrm{Fe}_{2} \mathrm{O}_{5}$, the brown millerite- $\mathrm{Sr}_{2} \mathrm{Fe}_{2} \mathrm{O}_{5} / / \mathrm{SrCoO}_{2.7}$ mixture showed high specific capacitance [99]. It is reported that the Cubic structure of perovskite materials may provide three-dimensional diffusion channels, which can aid oxygen anion diffusion. A cubic structured strontium titanate was studied for its charge storage property by Anuj Kumar Tomar et al. Strontium titanate electrode displayed a capacitance value of $592 \mathrm{~F} \mathrm{~g}^{-1}$ at $5 \mathrm{mV} \mathrm{s}^{-1}$ as anticipated from its 
mesoporous structure, large specific surface area and good mass transfer rate. A high specific capacitance of $212.5 \mathrm{~F} \mathrm{~g}^{-1}$ at $0.63 \mathrm{~A} \mathrm{~g}^{-1}$ with good capacitance retention of up to $74.5 \%$ and excellent cycling stability was reported for the developed symmetric supercapacitor cell in aqueous media [100].
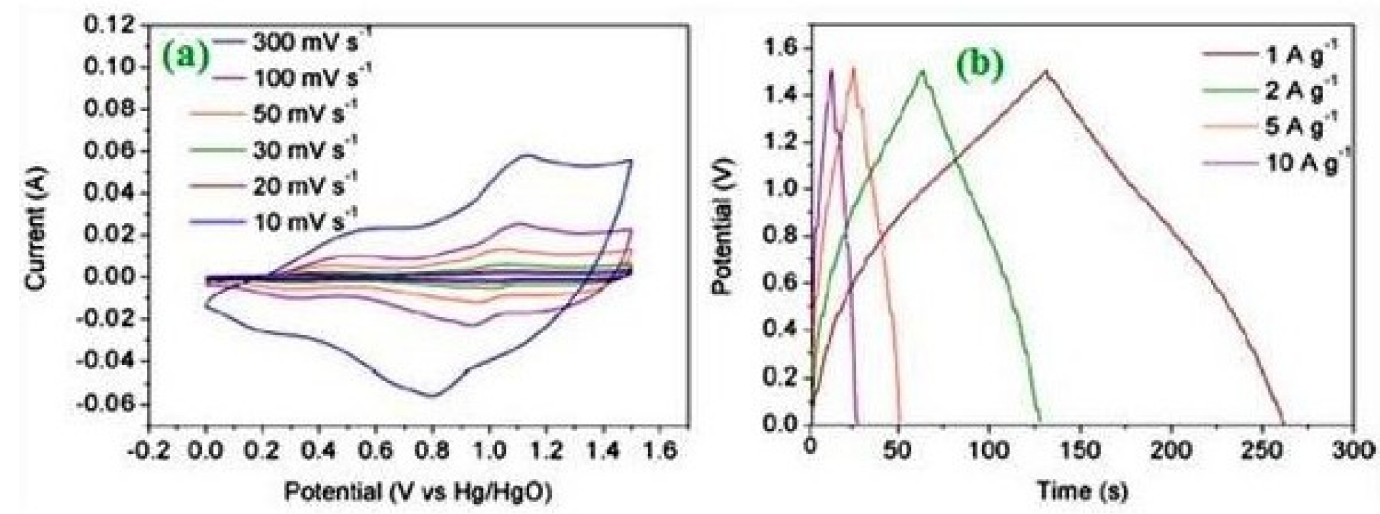

Figure 8. (a) The cyclic voltammetric curves in SC//AC ASC at different scanning rates (b) Galvanostatic charge/discharge curves at different current densities of the SC//AC ASC. Reprinted with permission from [97]. Copyright (2016), American Chemical Society.

In recent years, supercapacitors have had superior specific capacity with good cycling stability using bimetallic perovskite, which has also been shown to be a promising candidate for supercapacitor applications. For example, Co-Mn perovskite fluorides $\left(\mathrm{KCo}_{x} \mathrm{Mn}_{1-\mathrm{x}} \mathrm{F}_{3}\right)$ studied for supercapacitors applications revealed that the material had a specific capacity and rate behavior combined with good cycling stability after 5000 cycles at $8 \mathrm{~A} \mathrm{~g}^{-1}$, and the AC//K-Co-Mn-F-based asymmetric supercapacitor exhibited excellent energy density and power density with a value of $8.0-2.4 \mathrm{Wh} \mathrm{Kg}^{-1}$ at $0.14-8.7 \mathrm{KW} \mathrm{Kg}^{-1}$ [101].

In another report, the light-sensitive photo-supercapacitor was reported as a potential source of energy storage with a high areal capacitance of $150 \mathrm{mF} \mathrm{cm}^{-2}$ and a capacitance loss of $4 \%$. They also found that the photo voltage and photocurrent is zero in the absence of light [102]. Organometallic halide perovskites were found to have excellent ionic responses though they are known for their electronic properties. Luqman et al. [103] have synthesized and developed cadmium sulfide quantum dots. The authors fabricated a cadmium sulfide quantum dots-based electrochemical capacitor as an active electrode of organometallic halide perovskite. Popoola et al. [104] fabricated solid-state perovskite electrochemical supercapacitors having an aerial capacitance of $21.50 \mu \mathrm{F} / \mathrm{cm}^{2}$, for an organometallic halide perovskite electrode, which is 3.65 times greater than similar perovskite electrochemical capacitors. Perovskite with $\mathrm{ABO}_{3}$ type exhibited enhanced performance, coarse $\mathrm{BO}_{2} \cdot x \mathrm{H}_{2} \mathrm{O}(2<\mathrm{x}<80)$ gels, free of anion contaminants reacting with $\mathrm{A}(\mathrm{OH})_{2}$ under refluxing conditions at $70-100{ }^{\circ} \mathrm{C}$, giving rise to crystallites of single phased, nanometer-size powders of $\mathrm{ABO}_{3}$ perovskites $(\mathrm{A}=\mathrm{Ba}$, $\mathrm{Sr}, \mathrm{Ca}, \mathrm{Mg}, \mathrm{Pb} ; \mathrm{B}=\mathrm{Zr}, \mathrm{Ti}$, Sn) [105]. Lattice relaxation on the surface of $\mathrm{PbTiO}_{3}$ and $\mathrm{BaTiO}_{3}$ was investigated under the assumption that the spurious lattice expansion in perovskite nanocrystals is caused by surface relaxation [106]. Jose et al. [107] synthesized and produced the barium europium zirconate nanoparticles, a complex perovskite oxide recorded from different applications based on supercapacitors of perovskite. Two binary oxide perovskite with general formula $\mathrm{A}_{2} \mathrm{BB}_{8} \mathrm{O}_{6}$ have been studied; for instance, $\mathrm{ZnAl}_{2} \mathrm{O}_{4}$ with a spinel structure has been prepared through the microemulsion process. The $\mathrm{LaMnO}_{3}$-based perovskite prepared by reverse microemulsion was found to have a peculiar doughnut-like texture with a diameter of $2 \mu \mathrm{m}$ [108]. The perovskite with the $\mathrm{LaNiO}_{3}$ phase exhibited a high specific capacitance value of $160 \mathrm{~F} \mathrm{~g}^{-1}$ at $10 \mathrm{mV} \mathrm{s}^{-1}$ for manganese oxide/ $\mathrm{LaNiO}_{3}$ electrodes [109]. Perovskite $\mathrm{KNi}_{0.8} \mathrm{Co}_{0.2} \mathrm{~F}_{3}$ nanocrystals have been introduced as potential electrode materials for supercapacitors, with superior specific capacity and rate behavior due to the optimal 
synergistic effect of $\mathrm{Ni}$ and $\mathrm{Co}$ redox species. The $\mathrm{AC} / / \mathrm{KNi}_{0.8} \mathrm{Co}_{0.2} \mathrm{~F}_{3}$ asymmetric capacitor delivered high power and energy densities together with excellent cycling stability [110].

The perovskite solar cells exhibit significant electron transport properties when they combine with zinc oxide $(\mathrm{ZnO})$ nanoparticles (NPs) at low temperatures. The authors suggest that this material may be used instead of titanium dioxide $\left(\mathrm{TiO}_{2}\right)$ to develop high-efficiency perovskite solar cells on flexible substrates. Zinc oxide nanoparticles use perovskite solar cells with high level performance. On the other hand, electrochemical devices are shown to be stationary partial to ZnO-NPs from the other electrochemical device, but still limited to ZnO-HAP. Cheng et al. studied the chemistry and crystal growth of organometal halides such as $\mathrm{CH}_{3} \mathrm{NH}_{3} \mathrm{PbI}_{3}$ containing perovskite on $\mathrm{ZnO}-\mathrm{NP}$ thin films. The polymeric buffer layer poly(ethylenimine) (PEI) was found to enhance power conversion efficiencies of perovskite photovoltaic cells to a value of $10.2 \%$. [111]. A rechargeable battery with bifunctional catalysts was studied recently for several applications. The bifunctional catalyst perovskite lanthanum nickel oxide nanoparticles with intertwined core corona structured morphology were studied to produce highly efficient energy storage devices [112]. Lanthanide has become an important element of anion supercapacitors; for example, perovskite $\mathrm{LaNiO}_{3}$ oxide, which has been found to show that $\mathrm{LaNiO}_{3}$ has a specific capacitance value of $478.7 \mathrm{~F} \mathrm{~g}^{-1}$ at $0.1 \mathrm{mV}^{-1}$, and has excellent cycling stability after 15,000 cycles with a slight decrease in charge discharge efficiency of about $5.5 \%$. The studies on the $\mathrm{LaNiO}_{3}$ electrode revealed that charge storage is closely related to the intercalation of oxygen-ion into oxygen vacancies, which originated from the different valence states of the $\mathrm{B}$ site, for example, $\mathrm{Ni}$ in perovskite $\mathrm{ABO}_{3}$ structure [113]. The carbon cloth electrode containing $28.6 \mathrm{mg} \mathrm{cm}^{-2}$ of Ag nanoparticles showed a volumetric capacitance of $262.5 \mathrm{~F} \mathrm{~cm}^{-3}$ at $1 \mathrm{~mA} \mathrm{~cm}^{-2}$, an aerial capacity of $14.8 \mathrm{~F} \mathrm{~cm}^{-2}$ and a specific capacitance of $517.5 \mathrm{~F} \mathrm{~g}^{-1}$, which retains $85.6 \%$ of its cycling stability after 3000 cycles. The Ag/LSC/carbon cloth electrode also showed a significant energy density of $21.9 \mathrm{mWh} \mathrm{cm}^{-3}$, the marked capacitive performance of the modified electrodes that result from porous, conductive and $\mathrm{Ag}$ nanoparticles [114]. Shankar et al. synthesized $\mathrm{NdCr}_{1-\mathrm{x}} \mathrm{Fe}_{\mathrm{x}} \mathrm{O}_{3}$ perovskites by the sol-gel auto-combustion process and studied the dielectric behavior at varying frequency and temperature. The $\mathrm{NdCr}_{1-x} \mathrm{Fe}_{\mathrm{x}} \mathrm{O}_{3}$ perovskites ceramic nanoparticles material showed a high dielectric constant in the order of $10^{7}$ at room temperature and were found to decrease proportionally to $\mathrm{Fe}$ content [115].

George et al. [116] have prepared nanofibers of $\mathrm{SrMnO}_{3}$ perovskite oxide through the sol-gel electrospinning method and the effect of doping $\mathrm{Ba} / \mathrm{Ca}$ on the specific capacitance of this nanofiber supercapacitor has been studied. A high specific capacitance value of $446.8 \mathrm{~F} \mathrm{~g}^{-1}$ is reported for the $\mathrm{SrMnO}_{3}$ electrode incorporated with barium, of about $20 \mathrm{~mol} \%$. Nano Ru-doped perovskites with graphene oxide are synthesized by doping $\mathrm{Sr}$, Ba or $\mathrm{Ca}$. The perovskite with a lower quantity of Ru was used as supercapacitor electrode and it was found that the electrodes had a specific capacitance of 564, 460, and $316 \mathrm{~F} \mathrm{~g}^{-1}$, respectively, for $\mathrm{Sr}^{-}, \mathrm{Ba}^{-}$and $\mathrm{Ca}^{-}$Graphene composites [117]. Hussian et al. [118] developed $\mathrm{NaNiF}_{3}$ hollow spheres asymmetric supercapacitor-based perovskite fluoride, which displays an energy density of $51.78 \mathrm{Wh} \mathrm{kg}^{-1}$ at a wide voltage window (1.65 V) with good cyclic stability. Ag nanoparticles embedded $\mathrm{La}_{0.85} \mathrm{Sr}_{0.15} \mathrm{MnO}_{3}$ were synthesized by Lang et al. [119] for supercapacitor study. The modified electrode showed a specific capacitance value of $186 \mathrm{~F} \mathrm{~g}^{-1}$ at $1 \mathrm{~A} \mathrm{~g}^{-1}$. The perovskite lanthanum aluminate has been synthesized by a hydrothermal method in the presence of reduced graphene oxide. This composite electrode showed $721 \mathrm{~F} \mathrm{~g}^{-1}$ of specific capacitance, which is higher than pure $\mathrm{LaAlO}_{3}$ and graphene oxide supercapacitors, whereas the chronopotentiometry studies on the graphene oxide $/ \mathrm{LaAlO}_{3}$ showed $283 \mathrm{~F} \mathrm{~g}^{-1}$ as specific capacitance [120]. Mn and $\mathrm{Nd}$ doping onto $\mathrm{LaFeO}_{3}$ produced $\mathrm{La}_{0.8} \mathrm{Nd}_{0.2} \mathrm{Fe}_{0.8} \mathrm{Mn}_{0.2} \mathrm{O}_{3}$, which showed an enhanced specific capacitance value of $158 \mathrm{~F} \mathrm{~g}^{-1}$ at $50 \mathrm{mV} / \mathrm{s}$, which is higher than that of the $\mathrm{LaFeO}_{3}$ electrode [121]. The recent research demonstrated that the organic-inorganic hybrid perovskites provide significant power conversion efficiency, suitable to be used in commercial applications. The hybrids based on polymers or an organic molecule with perovskite have been studied in detail by several authors. However, the utility of organic hole transport layers is limited due to the restrained electronic behavior of 
perovskite and the influence of reactive dopants [122], for instance, the devices made up of PEDOT/Py, $\mathrm{P}($ EDOT-co-MPy) and P(EDOT-co-PyMP) copolymers and carbon nanotube composite have been studied. The devices showed appreciable performance in supercapacitor studies with excellent cycling stability, as opposed to the poor cyclability anticipated from conjugated polymers [123]. Xu et al. [124] studied and developed a combined power pack of energy production (solar cell) with storage using $\mathrm{CH}_{3} \mathrm{NH}_{3} \mathrm{PbI}_{3}$ solar cell and a polypyrrole-containing hybrid supercapacitor. The polypyrrole-based hybrid supercapacitor is found to have a higher efficiency, approximately $10 \%$, than that of the photovoltaic cell with another type of supercapacitor. Polymer-loaded organic-inorganic hybrids are also synthesized and reported for supercapacitors by intercalating unsaturated compounds containing amine functional groups into the organic-inorganic laminar perovskite, followed by the polymerization of unsaturated amine compound using UV light irradiation [125].

Jain et al. have grown supercapacitor-containing thin films of manganite, with the general formula $\mathrm{RE}_{1 \mathrm{x}} \mathrm{M}_{x} \mathrm{MnO}_{3}$, with perovskite composite films of $\mathrm{La}_{1 \mathrm{x}} \mathrm{Sr}_{\mathrm{x}} \mathrm{MnO}_{3}, \mathrm{Pr}_{0.5} \mathrm{Ca}_{0.5} \mathrm{MnO}_{3}$ and $\mathrm{La}_{1 \mathrm{x}} \mathrm{Ca}_{x} \mathrm{MnO}_{3}$ on lanthanum aluminum oxide substrate. The prepared perovskite films were oriented along the epitaxial and c-axis, and exhibited high magnetoresistance [126]. Hou et al. [127] prepared a stable colloidal perovskite nanocrystal having a core-shell structure using a co-polymer template. The polymer template present in the nanoshell provides functionalization that may result in the production of functional nanodevices. Choi et al. [128] demonstrated water-resistant polythiophene derivatives obtained through photo-crosslinking PEDOT:PSS showing significant improvement in performance. $\mathrm{Xu}$ et al. [129] have shown that highly promising and oxygen-ion-intercalation type $\mathrm{B}$-site cation-containing $\mathrm{Ba}_{2} \mathrm{Bi}_{0.1} \mathrm{Sc}_{0.2} \mathrm{Co}_{1.7} \mathrm{O}_{6-\delta}$ perovskite oxide can also be effectively used as an electrode material for supercapacitor studies, having achieved a specific capacitance value of about $1050 \mathrm{~F} \mathrm{~g}^{-1}$ and an excellent cyclic stability (3000 cycles) in alkaline electrolyte $(6 \mathrm{M} \mathrm{KOH})$ solution (Figure 9).
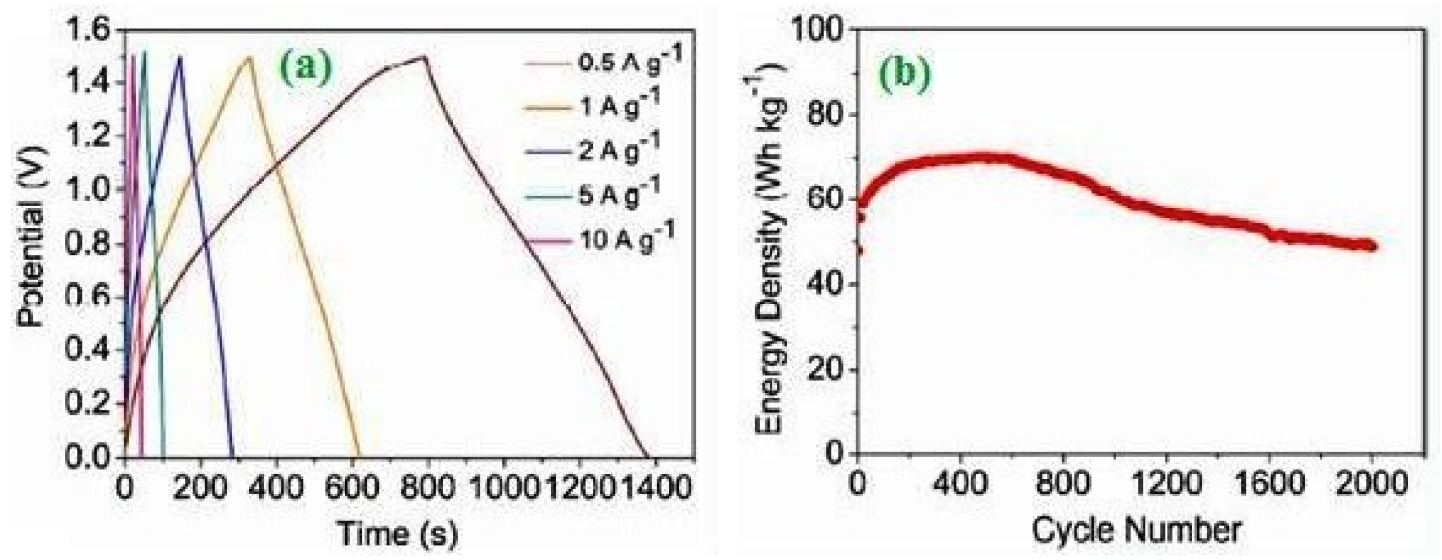

Figure 9. (a) Galvanostatic charge-discharge (GCD) curves at different current densities of $\mathrm{Ba}_{2} \mathrm{Bi}_{0.1} \mathrm{Sc}_{0.2} \mathrm{Co}_{1.7} \mathrm{O}_{6-\delta} / /$ anode cathode electrodes (BBSC//AC) and (b) Cycling stability of BBSC//AC at a current of $1 \mathrm{~A} \mathrm{~g}^{-1}$. Reprinted with permission from [129]. Copyright (2018), American Chemical Society.

\section{Electrochemical and Bio-Sensors}

Electrochemical bio-sensors are currently an area of focus and considerable attention is being given to detecting bio-sensing molecules using enzyme-free electrochemical techniques [130]. Perovskite-type $\mathrm{SrTiO}_{3}$ nanocubes decorated with reduced graphene oxide were synthesized using a sonochemical method. The modified electrode $\mathrm{SrTiO}_{3} @ \mathrm{RGO}$ nanocomposite has an excellent electrochemical detection toward amino acids (tryptophan, LOD of $7.15 \mathrm{nM}$ ) [131]. In addition, two different electrodes $\left(\mathrm{ZnSnO}_{3}\right.$ and ITO-coated polyethylene terephthalate (ITO/PET)) perovskite-based substrates have been produced, which have been reported as excellent electrode materials for the electrochemical detection of cardiac bio-marker troponin $\mathrm{T}$. The sensors were developed by electrochemical means in the concentration range of $1 \mathrm{fg} \mathrm{mL}^{-1}$ to $1 \mathrm{mg} \mathrm{mL}^{-1}$ and their LOD value was $0.187 \mathrm{fg} \mathrm{mL}^{-1}$ 
and $0.571 \mathrm{fg} \mathrm{mL}^{-1}$, respectively [34]. The perovskite material $\mathrm{SrPdO}_{3}$ modified with carbon paste $\left(\mathrm{CPE} / \mathrm{SrPdO}_{3}\right)$ electrode is being used in the growth of electrochemical sensing towards dopamine oxidation (DA) and the exhibited low level detection limit $(9.3 \mathrm{nM})$ with high sensitivity [132]. $\mathrm{Sr}_{0.85} \mathrm{Ce}_{0.15} \mathrm{FeO}_{3}$ perovskite (SCF) electrode materials play a significant role in electrochemical sensor and exhibited electrochemical detection of hydrogen peroxide $\left(\mathrm{H}_{2} \mathrm{O}_{2}\right)(\mathrm{LOD}=10 \mu \mathrm{M})$ with high sensitivity $\left(60 \mathrm{~mA} \mathrm{mM}^{-1} \mathrm{~cm}^{-2}\right)$ [133]. Ponnusamy et al. [134] reported the findings of crystal-structure-dependent nonenzymatic glucose-sensing properties of nanostructures of tungsten oxide $\left(\mathrm{WO}_{3}\right)$ and $\mathrm{Pd}$-doped $\mathrm{WO}_{3}$. The $\mathrm{WO}_{3}$ nanomaterials with orthorhombic, monoclinic, and mixed (ortho + monoclinic) phases were harvested using a simple hydrothermal method by varying the reaction time and subsequent annealing process. The Pd-doped $\mathrm{WO}_{3}$ exhibited a higher glucose-sensing

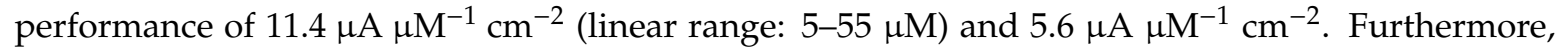
it was concluded that Pd-doped monoclinic $\mathrm{WO}_{3}$ is a possible material for the development of real-time glucose sensors (Figure 10). The development of perovskite-based $\mathrm{LaTiO}_{3}-\mathrm{Ag}_{0.1}$ nanocomposite is successfully utilized in the study of non-enzymatic electrochemiluminescence (ECL) glucose sensors, because they displayed their LOD value of $2.50 \times 10^{-9} \mathrm{M}$ with a high sensitivity of $7.80 \times 10^{2} \mu \mathrm{AmM}^{-1} \mathrm{~cm}^{-2}$ [135]. Ye et al. [136] have fabricated $\mathrm{LaNi}_{0.5} \mathrm{Ti}_{0.5} \mathrm{O}_{3} / \mathrm{CoFe}_{2} \mathrm{O}_{4}$ (LNT-CFO/GCE) perovskite-based nanocomposite towards $\mathrm{H}_{2} \mathrm{O}_{2}$ detection, which showed the reported detection limit value of $23 \mathrm{nM}$ by the amperometric method. Luque et al. [137] have stated the electrochemical properties of carbon-based manganese $\left(\mathrm{La}_{0.66} \mathrm{Sr}_{0.33} \mathrm{MnO}_{3}-\mathrm{CPE}\right)$ perovskite electrode for the sensitive determination of $\mathrm{H}_{2} \mathrm{O}_{2}$ reduction and oxidation (two commercial products). The strontium-supported reduced graphene oxide $\left(\mathrm{rGO}^{\mathrm{S}} \mathrm{SrTiO}_{3}\right)$ perovskite nanocomposite has been synthesized by an in-situ technique, in which the spherical morphological $\mathrm{rGO} / \mathrm{SrTiO}_{3}$ electrode displayed a better electrochemical response for para-nitrophenol [138]. A novel perovskite-type $\mathrm{LaNi}_{0.5} \mathrm{Ti}_{0.5} \mathrm{O}_{3}$ (LNT) coated carbon paste electrode (CPE) holds high promise in electrocatalytic activity and excellent long-term stability for the electrochemical detection of non-enzymatic glucose sensors [139].
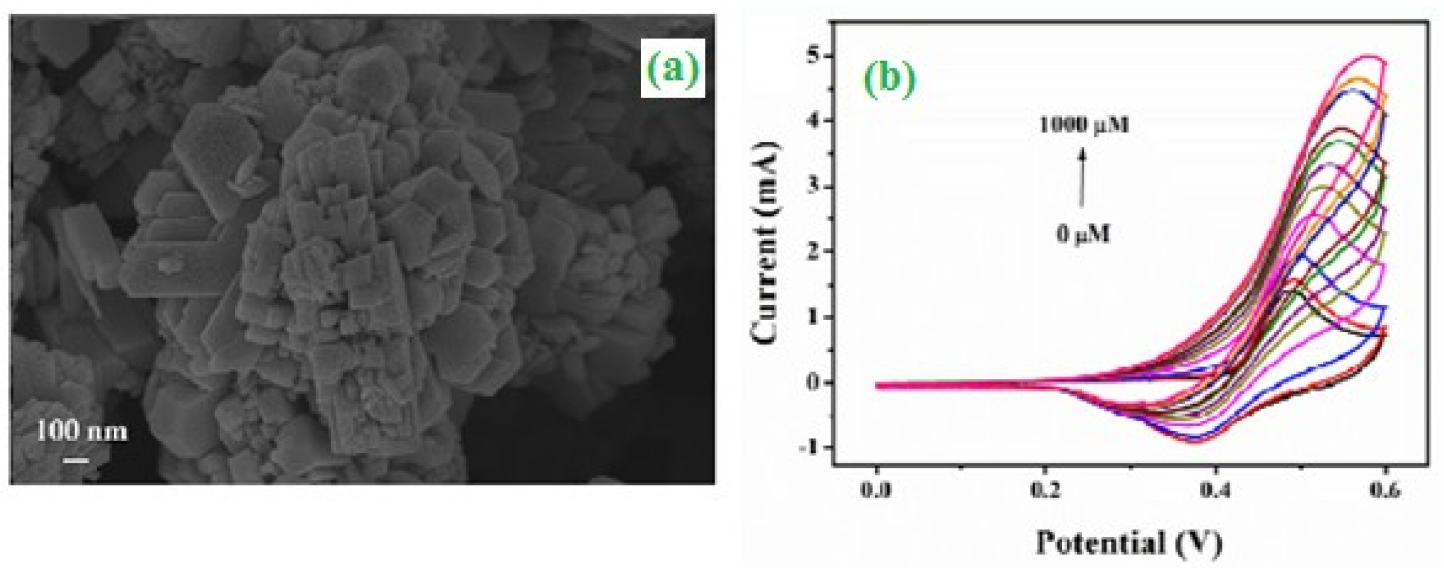

Figure 10. (a) High magnification FESEM micrographs of $\mathrm{WO}_{3}-\mathrm{Pd} \mathrm{AA}(\mathbf{b})$ Cyclic voltammagramme of $\mathrm{WO}_{3}$-Pd AA in presence of different concentrations of glucose. Reprinted with permission from [134]. Copyright (2018), American Chemical Society.

\section{Conclusions}

We have an overview of the recent development of different methods of preparation and fabrication of perovskite-based materials and their composite, a new and promising class of advanced electrode materials for various electrochemical applications like solar cells, batteries, fuel cells, etc. Nanostructured perovskite materials are currently of great interest in electrochemical energy storage devices owing to their high electrode surface area, size effects, unique structures, cost-effectiveness, mechanical flexibility, significantly enhanced electrochemical properties and long durability. The 
state-of-the-art electrode catalyst has been attracting interest in the expansion of green energy devices. The current challenges and forthcoming perspectives of perovskite materials in the framework of device stability, surface smooth electrode and low-cost device fabrication, which yield tremendous electrochemical performances in both electrochemical sensors and energy storage device applications, are discussed briefly. However, an in-depth discussion of various perovskite hybrid nanomaterials and their range of promising potential electrochemical application is accomplished.

Author Contributions: Conceptualization, S.-M.C.; Resources, R.R.; Supervision, S.-M.C.; Writing-Original Draft Preparation, R.R., S.-M.C., T.-W.C., K.D. and R.K.; Writing-Review \& Editing, R.R., S.-M.C., T.-W.C., G.A., K.D., R.K., N.K., N.B., T.J., V.M., S.D.R. and S.C. All authors have read and approved the final version of the manuscript.

Funding: S.-M.C. received funding from Ministry of Science and Technology (MOST 107-2113-M-027-005-MY3), Taiwan (ROC). R.R. received financial support from the Science \& Engineering Research Board (SERB), Government of India, New Delhi, File No: EEQ/2016/000427 and K.D. received funding from Science \& Engineering Research Board (SERB), Government of India, New Delhi, EEQ/2016/000049; Diary No: SERB/F/8355/2016-17.

Acknowledgments: We thank Shen-Ming Chen for help with manuscript review.

Conflicts of Interest: The authors declare no conflict of interest.

\begin{tabular}{ll}
\multicolumn{2}{l}{ Abbreviations } \\
PSC & Perovskite solar cell \\
LPK & Layered perovskite \\
LIBs & Lithium-ion batteries \\
SIBs & Sodium-ion batteries \\
PCE & Power conversion efficiency \\
PEDOT: PSS & Poly(3,4-ethylenedioxythiophene) and poly(styrene sulfonate) \\
FTO & Fluorinated indium tin oxide \\
CPSCs & Colorful perovskite solar cells \\
KIPIG & Potassium-ion pre-intercalated graphene \\
DSSCs & Dye-sensitized solar cells \\
IZO & Indium doped zinc oxide \\
HTM & Hole transporting materials \\
MAPbBr 3 & Methyl ammonium lead halide \\
AgNWs & Silver nanowires \\
SEM & Scanning electron microscope \\
ORR & Oxygen reduction reaction \\
OER & Oxygen evolution reaction \\
LiPS & Lithium Polysulfide \\
MOF & Metal-Organic Framework
\end{tabular}

\section{References}

1. Wu, M.; Zhang, G.; Wu, M.; Prakash, J.; Sun, S. Rational design of multifunctional air electrodes for rechargeable $\mathrm{Zn}$-Air batteries: Recent progress and future perspectives. Energy Storage Mater. 2019, 21, 253-286. [CrossRef]

2. Wali, Q.; Iftikha, F.J.; Khan, M.E.; Ullah, A.; Iqbal, Y.; Jose, R. Advances in stabiligy of perovskite solar cells. Org. Electron. 2020, 78, 105590. [CrossRef]

3. Dong, C.R.; Wang, Y.; Zhang, K.; Zeng, H. Halide perovskite materials as light harvesters for solar energy conversion. Energy Chem. 2020, 2, 100026. [CrossRef]

4. Jena, A.K.; Kulkarni, A.; Miyasaka, T. Halide perovskite photovoltaics: Background, status, and future prospects. Chem. Rev. 2019, 119, 3036-3103. [CrossRef]

5. Shellaiah, M.; Sun, K.W. Review on sensing applications of perovskite nanomaterials. Chemosensors 2020, 8 , 55. [CrossRef]

6. Zhu, Z.; Sun, Q.; Zhang, Z.; Dai, J.; Xing, G.; Li, S.; Huang, X.; Huang, W. Metal halide perovskites: Stability and sensing-ability. J. Mater. Chem. C 2018, 6, 10121-10137. [CrossRef] 
7. Boyd, C.C.; Cheacharoen, R.; Leijtens, T.; McGehee, M.D. Understanding degradation mechanisms and improving stability of perovskite photovoltaics. Chem. Rev. 2019, 119, 3418-3451. [CrossRef] [PubMed]

8. Assirey, E.A.R. Perovskite synthesis, properties and their related biochemical and industrial application. Saudi Pharm. J. 2019, 27, 817-829. [CrossRef] [PubMed]

9. Varma, P.C.R. perovskites. In Perovskite Photovoltaics; Academic Press: Thiruvananthapuram, Kerala, India, 2018; pp. 197-229.

10. Galloway, K.V.; Sammes, N.M. Fuel Cells—Solid Oxide Fuel Cells/Anodes. In Encyclopedia of Electrochemical Power Sources; Elsevier: Amsterdam, The Netherlands, 2009.

11. Yun, S.; Qin, Y.; Uhl, A.R.; Vlachopoulos, N.; Yin, M.; Li, D.; Han, X.; Hagfeldt, A. New-generation integrated devices based on dye-sensitized and perovskite solar cell. Energy Environ. Sci. 2018, 11, 476-526. [CrossRef]

12. Khan, U.; Zhinong, Y.; Khan, A.A.; Zulfiqar, A.; Khan, Q.U. Organic-inorganic hybrid perovskites based on methylamine lead halide solar cell. Sol. Energy 2019, 189, 421-425. [CrossRef]

13. Salim, T.; Sun, S.; Abe, Y.; Krishna, A.; Grimsdale, A.C.; Lam, Y.M. Perovskite-based solar cells: Impact of morphology and device architecture on device performance. J. Mater. Chem. A 2015, 3, 8943. [CrossRef]

14. Wang, J.; Choi, S.; Kim, J.; Cha, S.W.; Lim, J. Recent advances of first d-block metal-based perovskite oxide electrocatalyst for alkaline water splitting. Catalysts 2020, 10, 770. [CrossRef]

15. Hu, Y.; Schlipf, J.; Wusslerr, M.; Petrus, M.L.; Jaegermann, W.; Bein, T.; Buschbaum, P.M.; Docampo, P. Hybrid Perovskite/Perovskite Heterojunction Solar cells. ACS Nano 2016, 10, 5999-6007. [CrossRef] [PubMed]

16. Chiang, Y.F.; Jeng, J.Y.; Lee, M.H.; Peng, S.R.; Chen, P.; Guo, T.F.; Wen, T.C.; Hsu, Y.J.; Hsu, C.M. High voltage and efficient bilayer heterojunction solar cells based on organic-inorganic hybrid perovskite absorber with low-cost flexible substrate. Phys. Chem. Chem. Phys. 2014, 16, 6033-6040. [CrossRef] [PubMed]

17. Tong, G.; Chen, T.; Li, H.; Song, W.; Chang, Y.; Liu, J.; Yu, L.; Xu, J.; Qi, Y.; Jiang, Y. High Efficient Hole Extraction and Stable All-Bromide Inorganic Perovskite Solar Cells via Derivative-Phase Gradient Bandgap architecture. Sol. RRL 2019, 1900030. [CrossRef]

18. Wang, W.; Fleischer, C.; Sauer, D.U. Critical review of the methods for monitoring of lithium-ion batteries in electric and hybrid vehicles. J. Power Sources 2014, 258, 321-339.

19. Sun, N.; Liu, H.; Yu, Z.; Zhenning, Z.; Shao, C. Mn-doped $\mathrm{La}_{0.6} \mathrm{Sr}_{0.4} \mathrm{CoO}_{3}$ perovskite catalysts with enhanced performances for non-aqueous electrolyte $\mathrm{Li}^{-} \mathrm{O}_{2}$ batteries. $R S C$ Adv. 2016, 6, 13522. [CrossRef]

20. Liu, J.; Sheha, E.; Dek, S.I.E.; Goonetilleke, D.; Harguindeguey, M.; Sharma, N. $\mathrm{SmFeO}_{3}$ and Bi-doped $\mathrm{SmFeO}_{3}$ perovskites as an alternative class of electrodes in lithium-ion batteries. Cryst. Eng. Commun. 2018, 20, 6165-6172. [CrossRef]

21. Kong, L.; Chen, X.; Li, B.Q.; Peng, H.J.; Huang, J.Q.; Xie, J.; Zhang, Q. A Bifunctional Perovskite Promoter for Polysulfide Regulation toward Stable Lithium-Sulfur batteries. Adv. Mater. 2018, 30, 1705219. [CrossRef]

22. Cao, D.; Yin, C.; Shi, D.; Fu, Z.; Zhang, J.; Li, C. Cubic Perovskite Fluoride as Open Framework Cathode for Na-Ion batteries. Adv. Funct. Mater. 2017, 1701130. [CrossRef]

23. Chen, Y.; Zhou, W.; Ding, D.; Liu, M.; Ciucci, F.; Tade, M.; Shao, Z. Advances in Cathode Materials for Solid Oxide Fuel Cells: Complex Oxides without Alkaline Earth metal elements. Adv. Energy Mater. 2015, 5, 1500537. [CrossRef]

24. Wang, H.; Zhou, M.; Choudhury, P.; Luo, H. Perovskite oxides as bifunctional oxygen electrocatalysts for oxygen evolution/reduction reactions-A mini review. Appl. Mater. Today 2019, 16, 5671. [CrossRef]

25. Ge, X.; Sumboja, A.; Wu, D.; An, T.; Li, B.; Goh, F.W.T.; Hor, T.S.A.; Zong, Y.; Liu, Z. Oxygen Reduction in Alkaline Media: From Mechanisms to Recent Advances catalysts. ACS Catal. 2015, 5, 4643-4667. [CrossRef]

26. Zhou, W.; Ge, L.; Chen, Z.G.; Liang, F.; Xu, H.Y.; Motuzas, J.; Julbe, A.; Zhu, Z. Amorphous Iron Oxide Decorated 3D Hetero structured Electrode for Highly Efficient Oxygen reduction. Chem. Mater. 2011, 23, 4193-4198. [CrossRef]

27. Fabbri, E.; Mohamed, R.; Levecque, P.; Conrad, O.; Kotz, R.; Schmidt, T.J. Composite Electrode Boosts the Activity of $\mathrm{Ba}_{0.5} \mathrm{Sr}_{0.5} \mathrm{Co}_{0.8} \mathrm{Fe}_{0.2} \mathrm{O}_{3-\delta}$ Perovskite and Carbon toward Oxygen Reduction in alkaline media. ACS Catal. 2014, 4, 1061-1070. [CrossRef]

28. Zhou, W.; Sunarso, J.; Zhao, M.; Liang, F.; Klande, T.; Feldhoff, A. A Highly Active Perovskite Electrode for the Oxygen Reduction Reaction below $600^{\circ} \mathrm{C}$. Angew. Chem. Int. Ed. 2013, 52, 14036-14040. [CrossRef]

29. Jeyalakshmi, M.; Balasubramanian, K. Simple Capacitors to Supercapacitors-An Overview. Int. J. Electrochem. Sci. 2018, 3, 1196-1217. 
30. Zhang, Y.; Ding, J.; Xu, W.; Wang, M.; Shao, R.; Sun, Y.; Lin, B. Mesoporous $\mathrm{LaFeO}_{3}$ perovskite derived from MOF gel for all-solid-state symmetric supercapacitors. Chem. Eng. J. 2020, 386, 124030. [CrossRef]

31. Cao, Y.; Lin, B.; Sun, Y.; Yang, H.; Zhang, X. Symmetric/Asymmetric Supercapacitor Based on the Perovskite-type Lanthanum Cobaltate Nanofibers with Sr-substitution. Electrochim. Acta 2015, 178, 398-406. [CrossRef]

32. Hussain, S.; Javed, M.S.; Ullah, N.; Shaheen, A.; Aslam, N.; Ashraf, I.; Abbas, Y.; Wang, M.; Liu, G.; Qiao, G. Unique hierarchical mesoporous $\mathrm{LaCrO}_{3}$ perovskite oxides for highly efficient electrochemical energy storage applications. Ceram. Int. 2019, 45, 15164-15170. [CrossRef]

33. Park, S.; Boo, H.; Chung, T.D. Electrochemical non-enzymatic glucose sensors. Anal. Chim. Acta 2006, 556, 46-57. [CrossRef] [PubMed]

34. Supraja, P.; Sudarshan, V.; Tripathy, S.; Agarwal, A.; Singh, S.G. Label free electrochemical detection of cardiac biomarker troponin $\mathrm{T}$ using $\mathrm{ZnSnO}_{3}$ perovskite nanomaterials. Anal. Methods 2019, 11, 744-751. [CrossRef]

35. Hu, X.; Meng, X.; Zhang, L.; Zhang, Y.; Cai, Z.; Huang, Z.; Su, M.; Wang, Y.; Li, Y.; Yao, X.; et al. A Mechanically Robust Conducting Polymer Network Electrode for Efficient Flexible Perovskite solar cells. Joule 2019, 3, 2205-2218. [CrossRef]

36. Wei, W.; Li, M.; Hu, Y. Applications of 3D Potassium-Ion Pre-Intercalated Graphene for Perovskite and Dye-Sensitized solar cells. Ind. Eng. Chem. Res. 2019, 58, 8743-8749. [CrossRef]

37. Lee, W.J.; Ramasamy, E.; Lee, D.Y.; Song, J.S. Efficient Dye-Sensitized Solar Cells with Catalytic Multiwall Carbon Nanotube Counter electrodes. ACS Appl. Mater. Interfaces 2009, 6, 1145-1149. [CrossRef] [PubMed]

38. Wu, M.S.; Lin, J.C. Dual doping of mesoporous carbon pillars with oxygen and sulfur as counter electrodes for iodide/triiodide redox mediated dye-sensitized solar cells. Appl. Surf. Sci. 2019, 471, 455-461. [CrossRef]

39. Dong, G.; Xia, D.; Yang, Y.; Zhang, W.; Fan, R.; Sui, L.; Su, L.; Zhao, Y.; Yang, P.; Li, Y. In-situ passivation of $\mathrm{TiO}_{2}$ mesoporous scaffold with nano-sized heteropolyacid for boosting the efficiency of the perovskite solar cells. Electrochim. Acta 2020, 332, 135427. [CrossRef]

40. Joshi, P.; Zhang, L.; Chen, Q.; Glipeau, D.; Fong, H.; Qiao, Q. Electrospun Carbon Nanofibers as Low-Cost Counter Electrode for Dye-Sensitized Solar Cells. ACS Appl. Mater. Interfaces 2010, 12, 3572-3577. [CrossRef]

41. Yue, H.; Wu, J.; Xiao, Y.; Lin, J.; Huang, M.; Lan, Z.; Fan, L. Functionalized graphene/poly (3,4-ethylenedioxythiophene):polystyrenesulfonate as counter electrode catalyst for dye-sensitized solar cells. Energy 2013, 54, 315-321. [CrossRef]

42. Kavan, L.; Yum, J.H.; Gratzel, M. Optically Transparent Cathode for Dye-Sensitized Solar Cells Based on Graphene nanoplates. ACS Nano 2011, 5, 165-172. [CrossRef]

43. Wang, G.; Kuang, S.; Zhang, J.; Hou, S.; Nian, S. Graphitic carbon nitride/multiwalled carbon nanotubes composite as Pt-free counter electrode for high-efficiency dye-sensitized solar cells. Electrochim. Acta 2016, 187, 243-248. [CrossRef]

44. Hino, T.; Ogawa, Y.; Kuramoto, N. Preparation of functionalized and non-functionalized fullerene thin films on ITO glasses and the application to a counter electrode in a dye-sensitized solar cell. Carbon 2006, 44, 880-887. [CrossRef]

45. Torres, D.; Sebastian, D.; Lazzaro, M.J.; Pinilla, J.L.; Suelves, I.; Arico, A.S.; Baglio, V. Performance and stability of counter electrodes based on reduced few-layer graphene oxide sheets and reduced graphene oxide quantum dots for dye-sensitized solar cells. Electrochim. Acta 2019, 306, 396-406. [CrossRef]

46. Jost, M.; Alrecht, S.; Kegelmann, L.; Wolf, C.M.; Lang, F.; Lipovsek, B.; Krc, J.; Korte, L.; Neher, D.; Rech, B.; et al. Efficient Light Management by Textured Nanoimprinted Layers for Perovskite Solar Cells. ACS Photonics 2017, 4, 1232-1239. [CrossRef]

47. Ye, S.; Sun, W.; Li, Y.; Yan, W.; Peng, H.; Bian, Z.; Liu, Z.; Huang, C. CuSCN-Based Inverted Planar Perovskite Solar Cell with an Average PCE of 15.6\%. Nano Lett. 2015, 15, 3723-3728. [CrossRef] [PubMed]

48. Berhe, T.A.; Su, W.N.; Chen, C.H.; Pan, C.J.; Cheng, J.H.; Chen, H.M. Organometal halide perovskite solar cells: Degradation and stability. Energy Environ. Sci. 2016, 9, 323-356. [CrossRef]

49. Jiang, X.; Xiong, Y.; Mei, A.; Rong, Y.; Hu, Y.; Jin, Y.; Liu, Q.; Han, H. Efficient Compact-Layer-Free, Hole-Conductor Free, Fully Printable Mesoscopic Perovskite Solar cell. J. Phys. Chem. Lett. 2016, 7, 4142-4146. [CrossRef]

50. Jiang, Y.; Luo, B.; Jiang, F.; Hernandez, C.F.; Liu, T.; Mao, L.; Xiong, S.; Li, Z.; Wang, T.; Kippelen, B.; et al. Efficient colorful perovskite solar cells using a top polymer electrode simultaneously as spectrally selective antireflection coating. Nano Lett. 2016, 16, 7829-7835. [CrossRef] 
51. Denegri, G.M.; Colodrero, S.; Kamarenko, M.; Martorrell, J. All-Nanoparticle $\mathrm{SnO}_{2} / \mathrm{TiO}_{2}$ Electron-transporting layers processed at low temperature for efficient thin-film perovskite solar cells. ACS Appl. Energy Mater. 2018, 1, 5548-5556.

52. Chiang, Y.H.; Shih, C.K.; Sie, A.S.; Li, M.H.; Peng, C.C.; Shen, P.S.; Wang, Y.P.; Guo, T.F.; Chen, P. Highly stable perovskite solar cells with all-inorganic selective contacts from microwave-synthesized oxide nanoparticles. J. Mater. Chem. A 2017, 5, 25485. [CrossRef]

53. Li, Z.; Boix, P.P.; Xing, G.; Fu, K.; Kulkarnai, S.A.; Batabyal, S.K.; Xu, W.; Cao, A.; Sum, T.C.; Mathews, N.; et al. Carbon nanotubes as an efficient hole collector for high voltage methylammonium lead bromide perovskite solar cells. Nano Scale 2016, 8, 6352-6360. [CrossRef] [PubMed]

54. Dai, X.; Zhang, Y.; Shen, H.; Luo, Q.; Zhao, X.; Li, J.; Lin, H. Working from Both Sides: Composite Metallic Semitransparent Top Electrode for High Performance Perovskite solar cells. ACS Appl. Mater. Interfaces 2016, 8, 4523-4531. [CrossRef] [PubMed]

55. Ito, N.; Kamarudin, M.A.; Hirotani, D.; Zhang, Y.; Shen, Q.; Ogomi, Y.; Iikubo, S.; Minemoto, T.; Yoshino, K.; Hayase, S. Mixed Sn-Ge Perovskite for Enhanced Perovskite Solar Cell Performance in Air. J. Phys. Chem. Lett. 2018, 9, 1682-1688. [CrossRef] [PubMed]

56. Tavakoli, M.M.; Tavakoli, R.; Hasanzadeh, S.; Mirfasin, M.H. Interface Engineering of Perovskite Solar Cell Using a Reduced-Graphene Scaffold. J. Phys. Chem. C 2016, 120, 19531-19536. [CrossRef]

57. Bhaskar, A.; Mikhailova, D.; Yuvuz, N.K.; Nikolowski, K.; Oswald, S.; Braminik, N.N.; Ehrenberg, H. 3d-Transition metal doped spinels as high-voltage cathode materials for rechargeable lithium-ion batteries. Prog. Solid State Chem. 2014, 42, 128-148. [CrossRef]

58. Goriparti, S.; Miele, E.; Angelis, F.D.; Fabrizio, E.D.; Zaccaria, R.P.; Capiglia, C. Review on recent progress of nanostructured anode materials for Li-ion batteries. J. Power Sources 2014, 257, 421-443. [CrossRef]

59. Krass, S.; Vijn, A.; Falk, M.; Ufer, B.; Luerben, B.; Janek, J.; Froba, M. Nanostructured and nanoporous $\mathrm{LiFePO}_{4}$ and $\mathrm{LiNi}_{0.5} \mathrm{Mn}_{1.5} \mathrm{O}_{4-\delta}$ as cathode materials for lithium-ion batteries. Prog. Solid State Chem. 2014, 42, 218-241. [CrossRef]

60. Zhang, X.; Gong, Y.; Li, S.; Sun, C. Porous Perovskite $\mathrm{La}_{0.6} \mathrm{Sr}_{0.4} \mathrm{Co}_{0.8} \mathrm{Mn}_{0.2} \mathrm{O}_{3}$ Nanofibers Loaded with $\mathrm{RuO}_{2}$ Nano sheets as an Efficient and Durable Bifunctional Catalyst for Rechargeable Li-O $\mathrm{O}_{2}$ Batteries. ACS Catal. 2017, 7, 7737-7747. [CrossRef]

61. Miao, H.; Wang, Z.; Wang, Q.; Sun, S.; Xue, Y.; Wang, F.; Zhao, J.; Liu, Z.; Yuan, J. A new family of Mn-based perovskite $\left(\mathrm{La}_{1-\mathrm{x}} \mathrm{Y}_{\mathrm{x}} \mathrm{MnO}_{3}\right)$ with improved oxygen electrocatalytic activity for metal-air batteries. Energy 2018, 154, 561-570. [CrossRef]

62. Wang, J.; Cheng, X.; Li, Z.; Xu, M.; Lu, Y.; Liu, S.; Zhang, Y.; Sun, C. Perovskite $\mathrm{Sr}_{0.9} \mathrm{Y}_{0.1} \mathrm{CoO}_{3-\delta}$ Nano rods Modified with $\mathrm{CoO}$ Nanoparticles as a Bifunctional Catalyst for Rechargeable Li-O $\mathrm{O}_{2}$ Batteries. ACS Appl. Energy Mater. 2018, 1, 5557-5566.

63. Tong, W.; Yoon, W.S.; Hagh, N.M.; Amatucci, G.G. A Novel Silver Molybdenum Oxy fluoride Perovskite as a Cathode Material for Lithium batteries. Chem. Mater. 2009, 21, 2148. [CrossRef]

64. Liu, K.; Zhang, R.; Sun, J.; Wu, M.; Zhao, T. Polyoxyethylene (PEO)|PEO-Perovskite|PEO Composite Electrolyte for All-Solid-State Lithium Metal batteries. ACS Appl. Mater. Interfaces 2019, 11, 46930-46937. [CrossRef] [PubMed]

65. Fujii, Y.; Ramirez, D.; Navarro, N.C.R.; Jullian, D.; Miura, A.; Jaramillo, F.; Tadanaga, K. Two-Dimensional Hybrid Halide Perovskite as Electrode Materials for All-Solid-State Lithium Secondary Batteries Based on Sulfide Solid Electrolytes. ACS Appl. Energy Mater. 2019, 2, 6569-6576. [CrossRef]

66. Ramirez, D.; Suto, Y.; Cavarro, C.R.; Miura, A.; Tadanaga, K. Structural and Electrochemical Evaluation of Three and Two Dimensional Organohalide Perovskites and Their Influence on the Reversibility of Lithium intercalation. Inorg. Chem. 2018, 57, 4181-4188. [CrossRef]

67. Ogunniran, K.O.; Murugadoss, G.; Thangamuthu, R.; Periyasamy, P. All inorganic based $\mathrm{Nd}_{0.9} \mathrm{Mn}_{0.1} \mathrm{FeO}_{3}$ perovskite for Li-ion battery application: Synthesis, structural and morphological investigation. J. Alloys Compd. 2018, 766, 1014-1023. [CrossRef]

68. Veerappan, G.; Yoo, S.; Zhang, K.; Ma, M.; Kang, B.; Park, J.H. High-reversible capacity of Perovskite $\mathrm{BaSnO}_{3} / \mathrm{rGO}$ composite for Lithium-Ion Battery Anodes. Electrochim. Acta 2016, 214, 31-37. [CrossRef] 
69. Liu, G.; Chen, H.; Xia, L.; Wang, S.; Ding, L.X.; Li, D.; Xiao, K.; Dai, S.; Wang, H. Hierarchical Mesoporous/Macroporous Perovskite $\mathrm{La}_{0.5} \mathrm{Sr}_{0.5} \mathrm{CoO}_{3-x}$ Nanotubes: A Bifunctional Catalyst with Enhanced Activity and Cycle Stability for Rechargeable Lithium Oxygen batteries. ACS Appl. Mater. Interfaces 2015, 7, 22478-22486. [CrossRef]

70. Ma, Z.; Yuan, X.; Li, L.; Ma, Z.F. Double Perovskite Oxide $\mathrm{Sr}_{2} \mathrm{CrMoO}_{6-\delta}$ as an Efficient Electrocatalyst for Rechargeable Lithium Air batteries. Chem. Comm. 2014, 50, 14855-14858. [CrossRef]

71. Oh, M.Y.; Lee, J.J.; Zuhoor, A.; Gnanakumar, G.; Nahm, K.S. Enhanced electrocatalytic activity of three-dimensionally-ordered macroporous $\mathrm{La}_{0.6} \mathrm{Sr}_{0.4} \mathrm{CoO}_{3-\delta}$ perovskite oxide for $\mathrm{Li}-\mathrm{O}_{2}$ battery applications. RSC Adv. 2016, 6, 32212-32219. [CrossRef]

72. Zhang, Y.Q.; Tao, H.B.; Chen, Z.; Li, M.; Sun, Y.F.; Hua, B.; Luo, J.L. In situ grown cobalt phosphide (CoP) on perovskite nanofibers as an optimized trifunctional electrocatalyst for $\mathrm{Zn}$-air batteries and overall water splitting. J. Mater. Chem. A 2019, 7, 26607-26617. [CrossRef]

73. Larramendi, I.R.; Vitoriano, N.O.; Dzul Bautista, I.B.; Rojo, T. Chapter 20, Designing perovskite oxides for solid oxide fuel cells. In Perovskite Materials_Synthesis, Characterisation, Properties, and Applications; Intech Open Limited: London, UK, 2016; pp. 590-617. [CrossRef]

74. Chen, Y.; Nie, X.; Wang, B.; Xia, C.; Dong, W.; Wang, X.; Wang, H.; Zhu, B. Tuning $\mathrm{La}_{0.6} \mathrm{Sr}_{0.4} \mathrm{Co}_{0.2} \mathrm{Fe}_{0.8} \mathrm{O}_{3-\delta}$ perovskite cathode as functional electrolytes for advanced low-temperature SOFCs. Catal. Today 2019, 1-9. [CrossRef]

75. Wang, H.; Zhang, X.; Zhang, W.; Wei, Z.; Guan, K.; Meng, J.; Meng, F.; Meng, J.; Liu, X. Enhancing catalysis activity of $\mathrm{La}_{0.6} \mathrm{Sr}_{0.4} \mathrm{Co}_{0.8} \mathrm{Fe}_{0.2} \mathrm{O}_{3-\delta}$ cathode for solid oxide fuel cell by a facile and efficient impregnation process. Int. J. Hydrogen Energy 2019, 44, 13757. [CrossRef]

76. Wang, L.; Wang, P.; Geng, C.; Cao, H.; Xu, C.; Cheng, J.; Hong, T. A novel core-shell LSCF perovskite structured electro catalyst with local hetero-interface for solid oxide fuel cells. Int. J. Hydrogen Energy 2020, 45, 11824-11833. [CrossRef]

77. Budiman, R.A.; Bangarinao, K.D.; Ishiyama, T.; Krishimoto, H.; Yamaji, K.; Horita, T.; Yokokawa, T. Influence of $\mathrm{Sr}$ and $\mathrm{Co}$ deficiency on the transport properties and oxygen reduction reaction of $\mathrm{La}_{0.6} \mathrm{Sr}_{0.4} \mathrm{Co}_{0.2} \mathrm{Fe}_{0.8} \mathrm{O}_{3-\delta}$. Solid State Ion. 2020, 348, 115285. [CrossRef]

78. Gomez, A.E.M.; Sacanell, J.; Iriart, C.H.; Ramos, C.P.; Soldati, A.L.; Figueroa, S.J.A.; Tabacniks, M.H.; Fantini, M.C.A.; Craievich, A.F.; Lamas, D.G. Crystal structure, cobalt and iron speciation and oxygen nonstoichiometry of $\mathrm{La}_{0.6} \mathrm{Sr}_{0.4} \mathrm{Co}_{1-\mathrm{y}} \mathrm{Fe}_{\mathrm{y}} \mathrm{O}_{3-\mathrm{d}}$ nano rods for IT-SOFC cathodes. J. Alloys Compd. 2020, 817, 153250. [CrossRef]

79. Li, P.; Yang, Q.; Zhang, H.; Yao, M.; Yan, F.; Fu, D. Effect of Fe, Ni and Zn dopants in $\mathrm{La}_{0.9} \mathrm{Sr}_{0.1} \mathrm{CoO}_{3}$ on the electrochemical performance of single-component solid oxide fuel cell. Int. J. Hydrogen Energy 2020, 45, 11802. [CrossRef]

80. Xie, D.; Li, K.; Yang, J.; Yan, D.; Jia, L.; Chi, B.; Pu, J.; Li, J. High-performance $\mathrm{La}_{0.5}\left(\mathrm{Ba}_{0.75} \mathrm{Ca}_{0.25}\right)_{0.5} \mathrm{Co}_{0.8} \mathrm{Fe}_{0.2} \mathrm{O}_{3-\delta}$ cathode for proton-conducting solid oxide fuel cells. Int. J. Hydrogen Energy 2020, 1-8. [CrossRef]

81. Zhang, W.; Wang, H.; Guan, K.; Wei, Z.; Zhang, X.; Meng, J.; Liu, X.; Meng, J. La ${ }_{0.6} \mathrm{Sr}_{0.4} \mathrm{Co}_{0.2} \mathrm{Fe}_{0.8} \mathrm{O}_{3-\delta} / \mathrm{CeO}_{2}$ Hetero structured Composite Nanofibers as a Highly Active and Robust Cathode Catalyst for Solid Oxide Fuel Cells. ACS Appl. Mater. Interfaces 2019, 11, 26830-26841. [CrossRef]

82. Wang, H.; Zhang, W.; Guan, K.; Wei, Z.; Meng, J.; Meng, J.; Liu, X. Enhancing Activity and Durability of A-Site-Deficient $\left(\mathrm{La}_{0.6} \mathrm{Sr}_{0.4}\right)_{0.95} \mathrm{Co}_{0.2} \mathrm{Fe}_{0.8} \mathrm{O}_{3-\delta}$ Cathode by Surface Modification with $\mathrm{PrO}_{2-\delta}$ Nanoparticles. ACS Sustain. Chem. Eng. 2020, 8, 3367-3380. [CrossRef]

83. Nadeem, M.; Wan, Y.; Xia, C. The effect of group IIIA oxides on the oxygen reduction reaction at cathodes for intermediate-temperature solid oxide fuel cells. Compos. Part B Eng. 2020, 189, 107924. [CrossRef]

84. Lai, Y.W.; Lee, K.R.; Yang, S.Y.; Tseng, C.J.; Jang, S.C.; Tsao, I.Y.; Chen, S.Y.; Lee, S.W. Production of $\mathrm{La}_{0.6} \mathrm{Sr}_{0.4} \mathrm{Co}_{0.2} \mathrm{Fe}_{0.8} \mathrm{O}_{3-\delta}$ cathode with graded porosity for improving proton-conducting solid oxide fuel cells. Ceram. Int. 2019, 45, 22479-22485. [CrossRef]

85. Ryu, S.; Lee, S.; Jeong, W.; Pandiyan, A.; Moorthy, S.B.K.; Chang, I.; Park, T.; Cha, S.W. Pulsed laser deposition of $\mathrm{BaCo}_{0.4} \mathrm{Fe}_{0.4} \mathrm{Zr}_{0.1} \mathrm{Y}_{0.1} \mathrm{O}_{3-\delta}$ cathode for solid oxide fuel cell. Surf. Coat. Technol. 2019, 369, 265-268. [CrossRef] 
86. Zhang, J.; Li, X.; Zhang, Z.; Xu, X.; Chen, Y.; Song, Y.; Dai, J.; Yang, G.; Ran, R.; Zhou, W.; et al. A new highly active and $\mathrm{CO}_{2}$-stable perovskite-type cathode material for solid oxide fuel cells developed from A- and B-site cation synergy. J. Power Sources 2020, 457, 227995. [CrossRef]

87. Namgung, Y.; Hong, J.; Kumar, A.; Lim, D.K.; Song, S.J. One step infiltration induced multi-cation oxide nanocatalyst for load proof SOFC application. Appl. Catal. B Environ. 2020, 267, 118374. [CrossRef]

88. Ge, X.; Du, Y.; Li, B.; Hor, T.S.A.; Sindoro, M.; Zong, Y.; Zhang, H.; Liu, Z. Intrinsically Conductive Perovskite Oxides with Enhanced Stability and Electrocatalytic Activity for Oxygen Reduction Reactions. ACS Catal. 2016, 6, 7865-7871. [CrossRef]

89. Gao, J.; Li, Q.; Xia, W.; Sun, L.; Huo, L.H.; Zhao, H. Advanced Electrochemical Performance and $\mathrm{CO}_{2}$ Tolerance of $\mathrm{Bi}_{0.5} \mathrm{Sr}_{0.5} \mathrm{Fe}_{1-\mathrm{x}} \mathrm{Ti}_{\mathrm{x}} \mathrm{O}_{3-\delta}$ Perovskite Materials as Oxygen Reduction Cathodes for Intermediate-Temperature Solid Oxide Fuel Cells. ACS Sustain. Chem. Eng. 2019, 7, 18647-18656. [CrossRef]

90. Wang, J.; Saccoccio, M.; Chen, D.; Gao, Y.; Chen, C. The effect of A-site and B-site substitution on $\mathrm{BaFeO}_{3-\delta}$; An investigation as a cathode material for intermediate-temperature solid oxide fuel cell. J. Power Sources 2015, 297, 511-518. [CrossRef]

91. Wang, G.; Zhang, L.; Zhang, J. A review of electrode materials for electrochemical supercapacitors. Chem. Soc. Rev. 2012, 41, 797-828. [CrossRef]

92. Zhou, F.; Ren, Z.; Zhao, Y.; Shen, X.; Wang, A.; Li, Y.Y.; Surya, C.; Chai, Y. Perovskite Photovoltachromic Supercapacitor with All-Transparent Electrodes. ACS Nano 2016, 10, 5900-5908. [CrossRef]

93. Li, X.; Zhao, H.; Xu, N.; Zhou, X.; Zhang, C.; Chen, N. Electrical conduction behavior of La, Co co-doped $\mathrm{SrTiO}_{3}$ perovskite as anode material for solid oxide fuel cells. Int. J. Hydrogen Energy 2009, 34, 6407-6414. [CrossRef]

94. Li, X.; Zhao, X.; Zhou, W.; Xu, N.; Xie, Z.; Chen, N. Electrical conductivity and structural stability of La-doped $\mathrm{SrTiO}_{3}$ with A-site deficiency as anode materials for solid oxide fuel cells. Int. J. Hydrogen Energy 2010, 35, 7913-7918. [CrossRef]

95. Yoo, K.B.; Choi, G.M. Performance of La-doped strontium titanate (LST) anode on $\mathrm{LaGaO}_{3}$-based SOFC. Solid State Ion. 2009, 180, 867-871. [CrossRef]

96. Lang, X.; Mo, H.; Hu, X.; Tian, H. Supercapacitor performance of perovskite $\mathrm{La}_{1-\mathrm{x}} \mathrm{Sr}_{\mathrm{x}} \mathrm{MnO}_{3}$. Dalton Trans. 2017, 46, 13720-13730. [CrossRef] [PubMed]

97. Liu, Y.; Dinh, J.; Tade, M.O.; Shao, Z. Design of Perovskite Oxides as Anion-Intercalation-Type Electrodes for Supercapacitors: Cation Leaching Effect. ACS Appl. Mater. Interfaces 2016, 8, 23774-23783. [CrossRef]

98. Zhu, L.; Liu, Y.; Su, C.; Zhou, W.; Liu, M.; Shao, Z. Perovskite $\mathrm{SrCo}_{0.9} \mathrm{Nb}_{0.1} \mathrm{O}_{3-\delta}$ as an Anion-Intercalated Electrode Material for Supercapacitors with Ultrahigh Volumetric Energy Density. Angew. Chem. 2016, 128, 9728-9731. [CrossRef]

99. Alexander, C.T.; Mefford, J.T.; Saunders, J.; Forslund, R.P.; Johnston, K.P.; Stevenson, K.J. Anion-Based Pseudocapacitance of the Perovskite Library $\mathrm{La}_{1-x} \mathrm{Sr}_{\mathrm{x}} \mathrm{BO}_{3-\delta}(\mathrm{B}=\mathrm{Fe}, \mathrm{Mn}, \mathrm{Co})$. ACS Appl. Mater. Interfaces 2019, 11, 5084-5094. [CrossRef]

100. Tomar, A.K.; Singh, G.; Sharma, R.K. Charge storage characteristics of mesoporous strontium titanate perovskite aqueous as well as flexible solid-state supercapacitor cell. J. Power Sources 2019, 426, 223-232. [CrossRef]

101. Shi, W.; Ding, R.; Li, X.; Xu, Q.; Ying, D.; Huang, Y.; Liu, E. Bimetallic Co-Mn perovskite fluorides as high-stable electrode materials for supercapacitors. Chem. Eur. J. 2017, 23, 15305-15311. [CrossRef]

102. Ng, C.H.; Lim, H.N.; Hayase, S.; Zainal, Z.; Shafie, S.; Lee, H.W.; Huang, N.M. Cesium Lead Halide Inorganic-Based Perovskite-Sensitized Solar Cell for PhotoSupercapacitor Application Under High Humidity Condition. ACS Appl. Energy Mater. 2018, 1, 692-699. [CrossRef]

103. Luqman, E.; Oloore, E.; Gondal, M.A.; Idris, K.; Popoola, A. CdS Quantum Dots-Organometallic Halide Perovskites Bilayer Electrodes Structures for Supercapacitor Applications. Chem. Electron. Chem. 2019, 7, 486-492.

104. Popoola, I.; Gondal, M.; Oloore, L.; Popoola, A.; AlGhamdi, J. Fabrication of organometallic halide perovskite electrochemical supercapacitors utilizing quasi-solid-state electrolytes for energy storage devices. Electrochim. Acta 2020, 332, 135536. [CrossRef]

105. Kutty, T.R.N.; Padmini, P. Wet chemical formation of nanoparticles of binary perovskites through isothermal gel to crystallite conversion. Mater. Res. Bull. 1992, 27, 945-952. [CrossRef] 
106. Ishikawa, K.; Uemori, T. Surface relaxation in ferroelectric perovskites. Phys. Rev. B 1991, 60, 11841. [CrossRef]

107. Jose, R.; James Asha, J.; John, M.; Divakar, R.; Koshy, J. Synthesis and characterization of nanoparticles of $\mathrm{Ba}_{2} \mathrm{EuZrO}_{5.5}$ : A new complex perovskite ceramic oxide. J. Mater. Res. 2000, 15, 2125-2130. [CrossRef]

108. Giannakas, A.E.; Vaimakis, T.C.; Ladavos, A.K.; Trikalitis, P.N.; Pomonis, P.J. Variation of surface properties and textural features of spinel $\mathrm{ZnAl}_{2} \mathrm{O}_{4}$ and perovskite $\mathrm{LaMnO}_{3}$ nanoparticles prepared via CTAB-butanol-octane-nitrate salt microemulsions in the reverse and bicontinuous states. J. Colloid Interface Sci. 2003, 259, 244-253. [CrossRef]

109. Hwang, D.K.; Kim, S.; Lee, J.H.; Hwang, I.S.; Kim, I.D. Phase evolution of perovskite $\mathrm{LaNiO}_{3}$ nanofibers for supercapacitor application and p-type gas sensing properties of LaOCl-NiO composite nanofibers. J. Mater. Chem. 2011, 21, 1959-1965. [CrossRef]

110. Ding, R.; Li, X.; Shi, W.; Xu, Q.; Han, X.; Zhou, Y.; Hong, W.; Liu, E. Flexible high efficiency perovskite solar cells. Energy Environ. Sci. 2015, 8, 3208-3214.

111. Cheng, Y.; Yang, Q.D.; Xiao, J.; Xue, Q.; Li, H.W.; Guan, Z.; Yip, H.L.; Tsang, S.W. On the Decomposition of Organometal Halide Perovskite Films on Zinc Oxide Nanoparticles. ACS Appl. Mater. Interfaces 2015, 7, 19986-19993. [CrossRef]

112. Lee, D.U.; Park, H.W.; Park, M.G.; Ismayilov, V.; Chen, Z. Synergistic Bifunctional Catalyst Design based on Perovskite Oxide Nanoparticles and Intertwined Carbon Nanotubes for Rechargeable Zinc-Air Battery Applications. ACS Appl. Mater. Interfaces 2015, 7, 902-910. [CrossRef]

113. Che, W.; Wei, M.; Sang, Z.; Ou, Y.; Liu, Y.; Liu, J. Perovskite $\mathrm{LaNiO}_{3-\delta}$ oxide as an anion-intercalated pseudocapacitor electrode. J. Alloys Compd. 2018, 731, 381-388. [CrossRef]

114. Liu, P.; Liu, J.; Cheng, S.; Cai, W.; Yu, F.; Zhang, Y.; Wu, P.; Liu, M. A high-performance electrode for supercapacitors: Silver nanoparticles grown on a porous perovskite-type material $\mathrm{La}_{0.7} \mathrm{~S}_{0.3} \mathrm{CoO}_{3-\delta}$ substrate. Chem. Eng. J. 2017, 328, 1-10. [CrossRef]

115. Shankar, J.; Prasad, B.V.; Suresh, M.B.; Kumar, R.V.; Babu, D.S. Electrical Properties of $\mathrm{NdCr}_{1-\mathrm{x}} \mathrm{Fe}_{\mathrm{x}} \mathrm{O}_{3}$ Perovskite Ceramic Nanoparticles-An Impedance Spectroscopy studies. Mater. Res. Bull. 2017, 94, 385-398. [CrossRef]

116. George, G.; Jackson, S.L.; Luo, C.Q.; Fang, D.; Luo, D.; Hu, D.; Wen, J.; Luo, Z. Effect of doping on the performance of high-crystalline $\mathrm{SrMnO}_{3}$ perovskite nanofibers as a supercapacitor electrode. Ceram. Int. 2018, 44, 21982-21992. [CrossRef]

117. Galal, A.; Hassan, H.K.; Atta, N.F.; Jacob, T. Energy and cost-efficient nano-Ru-based perovskites/RGO composites for application in high performance supercapacitors. J. Colloid Interface Sci. 2019, 538, 578-586. [CrossRef] [PubMed]

118. Hussain, N.; Wu, F.; Younasd, W.; Xu, L. Hollow sphere formation by the self-aggregation of perovskite fluoride $\mathrm{NaNiF}_{3}$ nanocrystals and the application of these spheres as an electrode in an ultrahigh performance asymmetric supercapacitor. New J. Chem. 2019, 43, 11959-11967. [CrossRef]

119. Lang, X.; Sun, X.; Liu, Z.; Nan, H.; Li, C.; Hu, X.; Tian, H. Ag nanoparticles decorated perovskite $\mathrm{La}_{0.85} \mathrm{Sr}_{0.15} \mathrm{MnO}_{3}$ as electrode materials for supercapacitors. Mater. Lett. 2019, 243, 34-37. [CrossRef]

120. Vinuthraj, T.N.; Hoskeri, P.A.; Muralidhara, H.B. Facile synthesis of perovskite Lanthanum aluminate and its green reduced graphene oxide composite for high performance supercapacitors. J. Electroanal. Chem. 2020, 858, 113830. [CrossRef]

121. Rezanezhad, A.; Rezaie, E.; Ghadimi, L.S.; Hajalilou, A.; Lotf, E.A.; Arsalani, N. Outstanding supercapacitor performance of $\mathrm{Nd}-\mathrm{Mn}$ co-doped perovskite $\mathrm{LaFeO}_{3} @$ nitrogen-doped graphene oxide nanocomposites. Electrochim. Acta 2020, 335, 135699. [CrossRef]

122. Ishida, N.; Wakamiya, A.; Saeki, A. Quantifying Hole Transfer Yield from Perovskite to Polymer Layer: Statistical Correlation of Solar Cell Outputs with Kinetic and Energetic Properties. ACS Photonics 2016, 3, 1678-1688. [CrossRef]

123. Lacerda, G.R.D.B.S.; Santos, G.A.; Rocco, M.L.M.; Lavall, R.L.; Matencio, T.; Calado, T.H.D.R. Development of nanohybrids based on carbon nanotubes/P(EDOTco-MPy) and P(EDOT-co-PyMP) copolymers as electrode material for aqueous supercapacitors. Electrochim. Acta 2020, 335, 135637. [CrossRef]

124. Xu, X.; Li, S.; Zhang, H.; Shen, Y.; Zakeeruddin, S.M.; Grätzel, M.; Cheng, Y.B.; Wang, M. A Power Pack based on Organometallic Perovskite Solar Cell and Supercapacitor. ACS Nano 2015, 9, 1782-1787. [CrossRef] [PubMed] 
125. Takeoka, Y.; Asai, K. Perovskite-Type Organic/Inorganic Lamellar Polymer. U.S. Patent No: US6741,6927B2, 6 April 2004.

126. Jain, M.; Bauer, E.; Ronning, F.; Hundley, M.F.; Civale, L.; Wang, H.; Maiorov, B.; Burrell, A.K.; McClesky, T.M.; Foltyn, S.R.; et al. Mixed-Valence Perovskite Thin Films by Polymer-Assisted Deposition. J. Am. Ceram. Soc. 2008, 91, 1858-1863. [CrossRef]

127. Hou, S.; Guo, Y.; Tang, Y.; Quan, Q. Synthesis and Stabilization of Colloidal Perovskite Nanocrystals by Multidentate Polymer Micelles. ACS Appl. Mater. Interfaces 2017, 9, 18417-18422. [CrossRef] [PubMed]

128. Choi, H.; Ha, S.R.; Park, S.; Oh, J.T.; Kim, D.H.; Cho, S.; Bae, S.Y.; Kang, D.; Kim, J. Water-resistant PEDOT:PSS hole transport layer by photo crosslinking agent for high-performance perovskite and polymer solar cells. Nanoscale 2018, 10, 13187-13193.

129. Xu, Z.; Liu, Y.; Zhou, W.; Tade, M.O.; Shao, Z. B-Site Cation-Ordered Double-Perovskite Oxide as an Outstanding Electrode Material for Supercapacitive Energy Storage Based on the Anion Intercalation mechanism. ACS Appl. Mater. Interfaces 2018, 10, 9415-9423. [CrossRef]

130. Dai, H.; Zhang, Y.; Wu, X.; Hu, R.; Wang, L.; Zhang, Y.; Fan, G.; Hu, X.; Li, T.; Yang, Z. Synthesis of perovskite-type $\mathrm{SrTiO}_{3}$ nanoparticles for sensitive electrochemical bio-sensing applications. J. Electroanal. Chem. 2018, 810, 95-99. [CrossRef]

131. Govindasamy, M.; Wang, S.F.; Pan, W.C.; Subramanian, B.; Ramalingam, R.J.; Lohedan, H.A. Facile sonochemical synthesis of perovskite-type $\mathrm{SrTiO}_{3}$ nanocubes with reduced graphene oxide nanocatalyst for an enhanced electrochemical detection of $\alpha$-amino acid (tryptophan). Ultrason. Sonochem. 2019, 56, 193-199. [CrossRef]

132. Atta, N.F.; Ali, S.M.; Ads, E.H.E.; Galal, A. Nano-perovskite carbon paste composite electrode for the simultaneous determination of dopamine, ascorbic acid and uric acid. Electrochim. Acta 2014, 128, $16-64$. [CrossRef]

133. Deganello, F.; Liotta, L.F.; Loonardi, S.G.; Neri, G. Electrochemical properties of Ce-doped $\mathrm{SrFeO}_{3}$ perovskites-modified electrodes towards hydrogen peroxide oxidation. Electrochim. Acta 2016, 190, 939-947. [CrossRef]

134. Ponnusamy, R.; Chakraborty, B.; Rout, C.S. Pd Doped $\mathrm{WO}_{3}$ Nanostructures as Potential Glucose Sensor with Insight from Electronic Structure simulations. J. Phys. Chem. B 2018, 122, 2737-2746. [CrossRef]

135. Jia, F.F.; Zhong, H.; Zhang, W.G.; Li, X.R.; Wang, G.Y.; Song, J.; Chen, Z.P.; Yin, J.Z.; Guo, L.P. A novel nonenzymatic ECL glucose sensor based on perovskite $\mathrm{LaTiO}_{3}-\mathrm{Ag}_{0.1}$ nanomaterials. Sens. Actuators B 2015, 212, 174-182. [CrossRef]

136. Ye, D.; Xu, Y.; Luo, L.; Ding, Y.; Wang, Y.; Liu, X.; Xing, L.; Peng, J. A novel hydrogen peroxide sensor based on $\mathrm{LaNi}_{0.5} \mathrm{Ti}_{0.5} \mathrm{O}_{3} / \mathrm{CoFe}_{2} \mathrm{O}_{4}$ modified electrode. Colloids Surf. B 2012, 89, 10-14. [CrossRef] [PubMed]

137. Luque, G.L.; Ferreyra, N.F.; Leyva, A.G.; Rivas, G.A. Characterization of carbon paste electrodes modified with manganese based perovskites-type oxides from the amperometric determination of hydrogen peroxide. Sens. Actuators B 2009, 142, 331-336. [CrossRef]

138. Ahmad, K.; Mohammad, A.; Mathur, P.; Mobin, S.M. Preparation of $\mathrm{SrTiO}_{3}$ perovskite decorated $\mathrm{rGO}$ and electrochemical detection of nitroaromatics. Electrochim. Acta 2016, 215, 435-446. [CrossRef]

139. Wang, Y.; Xu, Y.; Luo, L.; Ding, Y.; Liu, X.; Huang, A. A novel sensitive nonenzymatic glucose sensor based on perovskite $\mathrm{LaNi}_{0.5} \mathrm{Ti}_{0.5} \mathrm{O}_{3}$-modified carbon paste electrode. Sens. Actuators B 2010, 151, 65-70. [CrossRef]

(C) 2020 by the authors. Licensee MDPI, Basel, Switzerland. This article is an open access article distributed under the terms and conditions of the Creative Commons Attribution (CC BY) license (http://creativecommons.org/licenses/by/4.0/). 